\begin{tabular}{|l|l|}
\hline $\begin{array}{l}\text { 2. To: (Receiving Organizatior): } \\
\text { RPP Safety Analysis }\end{array}$ & $\begin{array}{l}\text { 3. From: (Originating Organization) } \\
\text { RPP Licensing }\end{array}$ \\
\hline $\begin{array}{l}\text { 5. Proj./Prog./Dept./Div.: } \\
\text { RPP }\end{array}$ & $\begin{array}{l}\text { 6. Design Authority/Design Agent/Cog. Engr.: } \\
\text { G.L. Jones }\end{array}$ \\
\hline
\end{tabular}

8. Originator Remarks:

This document is being submitted for approval and release.

11. Receiver Remarks: None

\begin{abstract}
4. Related EDT No.:
$\mathrm{N} / \mathrm{A}$

7. Purchase Order No.:

N/A

9. Equip./Component No.:

$\mathrm{N} / \mathrm{A}$

10. System/Bldg./Facility:

RPP/244-CR Vault

12. Major Assm. Dwg. No.:

$\mathrm{N} / \mathrm{A}$
\end{abstract}

13. Permit/Permit Application No:

$\mathrm{N} / \mathrm{A}$

14. Required Response Date:

$6 / 14 / 99$

\begin{tabular}{|l|c|l|l|l|}
\hline \multicolumn{2}{|c|}{15.} & DATA TRANSMITTED \\
\hline $\begin{array}{l}\text { (A) } \\
\text { tem } \\
\text { No. }\end{array}$ & (B) Document/Drawing No. & $\begin{array}{c}\text { (C) Sheet } \\
\text { No. }\end{array}$ & $\begin{array}{l}\text { (D) Rev. } \\
\text { No. }\end{array}$ & (E) Title or Description of Data Transmitted \\
\hline 1 & HNF-4453 & N/A & 0 & Hazard Evaluation for \\
\hline & & & & $244-$ AR Vault \\
\hline & & & & \\
\hline & & & & \\
\hline & & & & \\
\hline & & & & \\
\hline
\end{tabular}

KEY

\begin{tabular}{|c|c|c|c|}
\hline (F) & $(G)$ & $(H)$ & $(I)$ \\
\hline $\begin{array}{c}\text { Approval } \\
\text { Desig- } \\
\text { nator }\end{array}$ & $\begin{array}{c}\text { Reason } \\
\text { for Trans- } \\
\text { mittal }\end{array}$ & $\begin{array}{c}\text { Origi- } \\
\text { nator } \\
\text { Dispo- } \\
\text { stion }\end{array}$ & $\begin{array}{c}\text { Receiv- } \\
\text { er } \\
\text { Dispo- } \\
\text { sition }\end{array}$ \\
\hline N/A & 2 & 1 & 1 \\
\hline & & & \\
\hline & & & \\
\hline & & & \\
\hline & & & \\
\hline
\end{tabular}

16.

\begin{tabular}{|c|l|}
\hline Approval Designator (F) & \\
\hline $\begin{array}{c}\text { E, S, Q, D OR N/A } \\
\text { (See W'HC-CM-3-5, } \\
\text { Sec. 12.7) }\end{array}$ & $\begin{array}{l}\text { 1. Approval } \\
\text { 2. Release }\end{array}$ \\
\hline
\end{tabular}

17.

Reason for Transmittal (G)

4. Review

5. Post-Review

6. Dist. (Receipt Acknow. Required)

\begin{tabular}{|ll}
\hline \multicolumn{2}{|c}{ Disposition (H) \& (I) } \\
$\begin{array}{ll}\text { 1. Approved } & \text { 4. Reviewed no/comment } \\
\text { 2. Approved w/comment } & \text { 5. Reviewed w/comment } \\
\text { 3. Disapproved w/comment } & \text { 6. Receipt acknowledged }\end{array}$ \\
\hline
\end{tabular}

SIGNATURE/DISTRIBUTION

(See Approval Designator for required signatures)

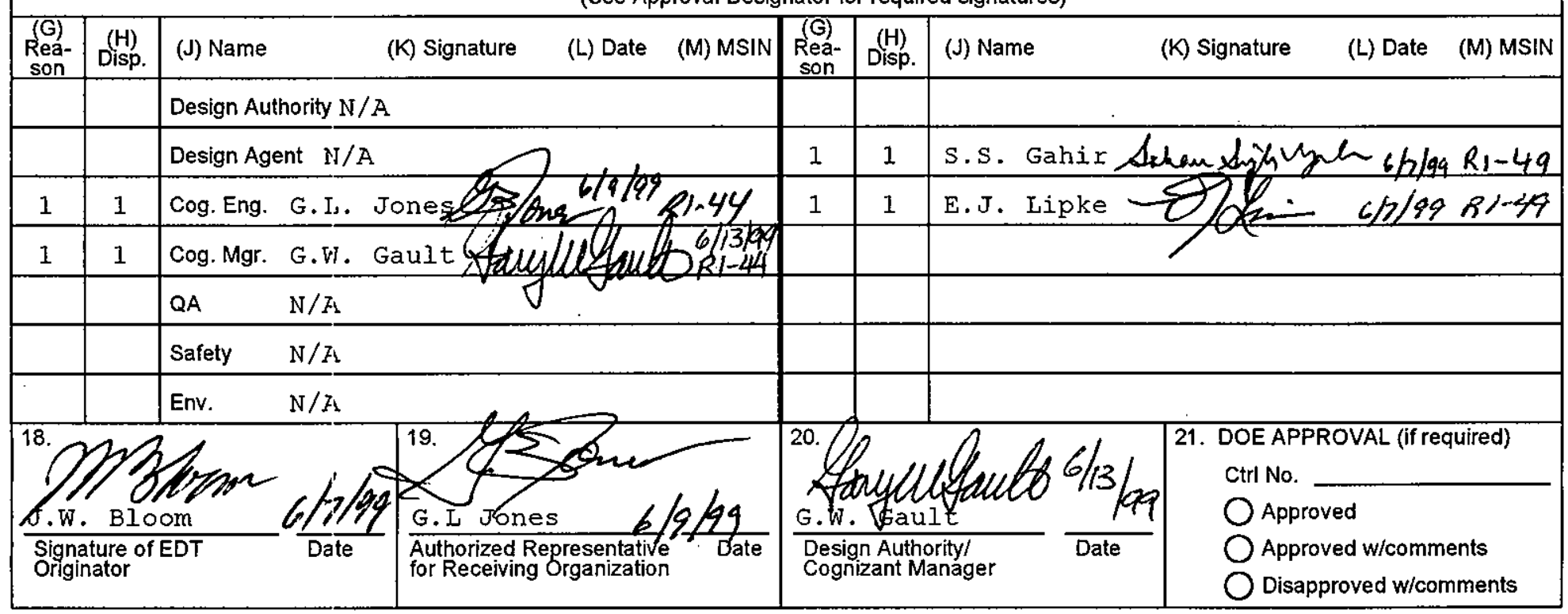




\section{HAZARD EVALUATION FOR 244-AR VAULT FACILITY}

\section{J. Braun}

Fluor Daniel Northwest Hanford, Richland, WA 99352

U.S. Department of Energy Contract DE-AC06-96RL13200

EDT/ECN: 626720

UC: 510

Org Code: $2 \mathrm{~N} 400$

B\&R Cocle: EW3130010

Charge Code: 101972

Total Pages: 7874

PF $6-15-99$

Key Words: 244-AR, Vault, Flooding, Hazard Evaluation, HAZOP

Abstract: This document presents the results of a hazard identification and evaluation performed on the 244-AR Vault Facility to close a USQ (USQ \#TF-98-0785, Potential Inadequacy in Authorization Basis (PIAB): To Evaluate Miscellaneous. Facilities Listed In HNF-2503 And Not Addressed In The TWRS Authorization Basis) that was generated as part of an evaluation of inactive TWRS facilities.

TRADEMARK DISCLAIMER. Reference herein to any specific commercial product, process, or service by trade name, trademark, manufacturer, or otherwise, does not necessarily constitute or imply its endorsement, recommendation, or favoring by the United States Government or any agency thereof or its contractors or subcontractors.

Printed in the United States of America. To obtain copies of this document, Box 950, Mailstop H6-08, Richland WA 99352, Phone (509) 372-2420; Fax

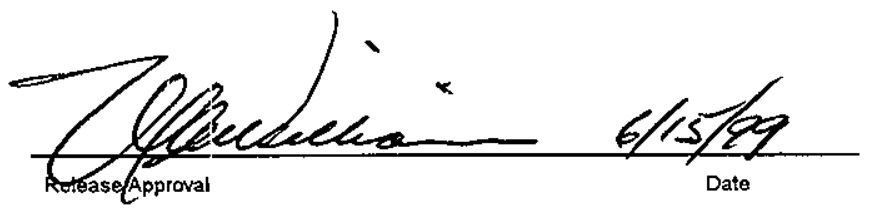

ontact: Document Control Soraces, P.O. 09) $376-4989$.

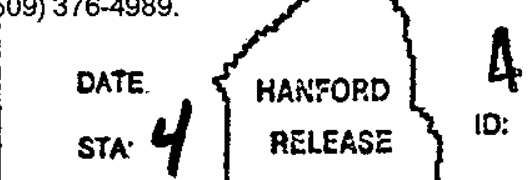

JUN 15 i999 
HNF-4453

Rev. 0

\title{
HAZARD EVALUATION FOR 244-AR VAULT FACILITY
}

\author{
Prepared by: \\ Fluor Daniel Northwest, Inc. \\ For: \\ Lockheed Martin Hanford Corporation
}

Date Published

June 1999

\section{Approved by: \\ Lockheed Martin Hanford Corporation June 1999}

Prepared for the U. S. Department of Energy

\section{FLUOR DANIEL \\ HANFORD, INC. Richland, Washington}

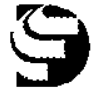

Hanford Management and Integration Contractor for the 
HNF-4453 Rev. 0

This page intentionally left blank 


\section{TABLE OF CONTENTS}

\subsection{INTRODUCTION}

1.1 PURPOSE

1.2 BACKGROUND

\subsection{DESCRIPTION}

2.1 MATERIALS STORED IN VAULT

2.2 BEST ESTIMATE OF RADIONUCLIDES IN 244-AR VAULT

2.3 FACILITY WALK DOWN INFORMATION

$2-5$

2.4 FACLITY OCCURRENCES

$2-6$

3.0 HAZARD IDENTIFICATION AND EVALUATION

3.1 METHODOLOGY

3.2 ASSUMPTIONS

$3-5$

3.3 EVALUATION

3-5

\subsection{CONCLÚSIONS}

5.0 REFERENCES

\section{TABLES}

Table 3-1. HAZOP Process Variables and Deviation Guide Words

\section{FIGURES}

Figure 2-1. 244-AR Vault Facility Schematic

\section{APPENDICES}

Appendix A. HAZOP Team Biographical Information 


\section{LIST OF TERMS}

$\mathrm{AB}$

AIChE

BIO

Cat

Con

DOE-RL

Env

Freq

GRE

Grp

HAZOP

ID

Mit

NC

PHA

Prev

Rep Acc

SSC

TBD

TSR

TWRS

USQ
Authorization Basis

American Institute of Chemical Engineers

Basis for Interim Operation

category

consequence

Department of Energy - Richland Operations Office

environmental

Frequency

gas release event

group

Hazards and Operability Analysis

identification

mitigative

No Controls

Preliminary Hazards Assessment

preventive

representative accident

structure, system, and component

to be determined

Technical Safety Requirement

Tank Waste Remediation System

Unreviewed Safety Question 


\subsection{INTRODUCTION}

\subsection{Purpose}

A hazard evaluation for the Hanford Site 244-AR Vault Facility was performed. The process and results of the hazard evaluation are provided in this document.

A previous hazard evaluation was performed for the 244-AR Vault Facility in 1996 in support of the Basis for Interim Operation (BIO) (HNF-SD-WM-BIO-001, 1998, Revision 1) of the Tank Waste Remediation System (TWRS). The results of that evaluation are provided in the BIO. Upon review of those results it was determined that hazardous conditions that could lead to the release of radiological and toxicological material from the 244-AR vaults due to flooding was not addressed in the original hazards evaluation. This supplemental hazard evaluation addresses this oversight of the original hazard evaluation.

The results of the hazard evaluation were compared to the current TWRS BIO to identify any hazardous conditions where Authorization Basis $(A B)$ controls may not be sufficient or may not exist. This document is not part of the $\mathrm{AB}$ and is not a vehicle for requesting changes to the $\mathrm{AB}$. It is only intended to provide information about hazardous conditions associated with the condition and configuration of the 244-AR vault facility. The $A B$ Control Decision process could be used to determine the applicability and adequacy of existing $\mathrm{AB}$ controls as well as any new controls that may be needed for the identified hazardous conditions associated with 244-AR vault flooding. This hazard evaluation does not constitute an accident analysis.

\subsection{Background}

The 244-AR Vault, located north and west of 241-A Tank Farm in the 200-E Area of the Hanford Site, was constructed in 1966. The vault was designed to remove, treat, and transfer waste from 241-A Tank Farm, 241-AX Tank Farm, and PUREX Facility to B-Plant for fission product removal; provide interim storage for PUREX Facility acid waste feed to B-Plant; and receive and distribute the neutralized high-level waste of B-Plant. The facility was a transfer station and a temporary storage and waste acidification facility. It supported the strontium and cesium recovery effort from PUREX waste at B-Plant.

Waste has not been transferred from 244-AR vault tanks since April of 1978. It was cleaned out with the exception of a total of 3029 liters of sludge in the four vault tanks. Some jetting of the vault sumps into the vault tanks has been done between 1978 and 1993. There have been no operations performed within the vault cells except for entries into the three vault cells for monitoring, minor maintenance and inspections. 
While most of the TWRS vaults are no more than an underground vault with tanks and transfer equipment, the 244-AR Vault is actually a self-contained processing facility. The major structures and components comprising this facility are as follows:

- Canyon building and process cells,

- Ventilation systems, and

- Control rooms.

In mid 1980's it was decided to upgrade the facility for interim storage of neutralized current acid waste (NCAW) from the aging waste tanks (AY/AZ) prior to being sent to B-Plant. The modification project included ventilation system upgrades, instrumentation upgrade and addition of a closed loop cooling system. About $90 \%$ of the modification project work was completed before it was suspended due to budget constraints.

The canyon ventilation system $(\mathrm{K}-2 / \mathrm{K}-3)$ is inoperable and has not been used since 1990 . The vessel ventilation system (K4) is also inoperable and has not been used since 1993. Although the vessel system has not operated since 1993, a portable exhauster has been installed and could be operated if needed instead of the original system.

There has been leakage of water into the vault cells in the past decade. The level of water in cell sumps has been observed to fluctuate after heavy rains, rapid snow melts, and water line breaks outside of facility. This is discussed further in Section 2.3 and Section 2.4 of this document. 


\subsection{DESCRIPTION}

The canyon/vault building of the 244-AR Vault Facility (Figure 2-1) is a reinforced concrete structure with $0.5 \mathrm{~m}(1.5 \mathrm{ft})$ thick walls. The canyon building measures $29 \mathrm{~m}(94 \mathrm{ft})$ by $5.5 \mathrm{~m}(18 \mathrm{ft})$ internally and is $11 \mathrm{~m}(36 \mathrm{ft})$. high above the process cell concrete cover blocks in the canyon floor. The canyon building also contains two shielded personnel access doors and a large, shielded motor-driven equipment access door that slides on a rail. A metal wind-reduction structure is attached to the East End of the building for weather protection when the equipment access doors are open.

Three process cells and 3 failed equipment storage tubes are located below the canyon floor. Each of the three process cells contains a sump with an overflow connection between Cell 1 and Cell 2. Cell 1 and Cell 2 have identical inside dimensions, $6.4 \mathrm{~m}(21 \mathrm{ft})$ square by $9.98 \mathrm{~m}(32.75 \mathrm{ft})$ deep. Cell 3 is $9.8 \mathrm{~m}(32 \mathrm{ft})$ long by $3.7 \mathrm{~m}(12 \mathrm{ft})$ wide by $6.4 \mathrm{~m}(21 \mathrm{ft})$ deep. The concrete cell walls are $0.6 \mathrm{~m}(2 \mathrm{ft})$ thick. The following four tanks are contained in the process cells:

- TK-244-AR-001 is located in Cell 1. This is a stainless steel flat-bottomed $163,315 \mathrm{~L}$ $(43,148 \mathrm{gal})$ tank, $6.1 \mathrm{~m}(20 \mathrm{ft})$ dia. and $6.02 \mathrm{~m}(19.75 \mathrm{ft})$ high. It was the primary storage tank for neutralized current acid waste (high-level first-cycle solvent extraction waste from the PUREX Facility).

- TK-244-AR-002 is located in Cell 2. It is a stainless steel Flat-bottomed 163,315 L $(43,148 \mathrm{gal}) \operatorname{tank}, 6.1 \mathrm{~m}(20 \mathrm{ft})$ dia. and $6.02 \mathrm{~m}(19.75 \mathrm{ft})$ high.

- TK-244-AR-003 is located in Cell 3. It is a stainless steel Slope-bottomed 18,143 L $(4,793 \mathrm{gal})$ tank, $2.9 \mathrm{~m}(9.5 \mathrm{ft})$ dia. and $2.7 \mathrm{~m}(9 \mathrm{ft})$ high.

- TK-244-AR-004 is located in Cell 3. It is a stainless steel Slope-bottomed 18,143 L $(4,793 \mathrm{gal})$ tank, $2.9 \mathrm{~m}(9.5 \mathrm{ft})$ dia. and $2.7 \mathrm{~m}(9 \mathrm{ft})$ high.

The failed equipment storage area is located next to Cell 1 at the East end of the canyon building. This storage area contains three storage tubes, each constructed of $1.4 \mathrm{~m}(4.5 \mathrm{ft})$ dia., 12 gauge, corrugated, galvanized pipe, that extend $11 \mathrm{~m}(35 \mathrm{ft})$ below the failed equipment storage area cover blocks. Each of the storage tubes has open drains to the Cell 1 floor. The storage tubes are vented to Cell 1 through $15.2 \mathrm{~cm}$ (6in.) dia. vent pipes located $6.7 \mathrm{~m}(22 \mathrm{ft})$ above the storage tube bottom. The storage tubes are covered with three $0.6 \mathrm{~m}(2 \mathrm{ft})$ thick reinforced concrete blocks.

Four ventilation systems formerly serviced the 244-AR Vault Facility:

- Control room ventilation system, $\mathrm{K}-1$

- Canyon intake ventilation system, K-2

- Canyon exhaust ventilation system, K-3

- Tank ventilation system, K-4. 
These systems are not currently operable and significant modifications or upgrades would be required to return these systems to service. The facility process area is passively ventilated to the building.

\subsection{Materials Stored in Vault}

The 244-AR Vault has not received wastes through the transfer system since the late 1970s. The cells and tanks within the facility currently contain wastes, as described below.

2.1.1 Cell 1: The Cell 1 is located between Cell 2 and the failed equipment storage area at the

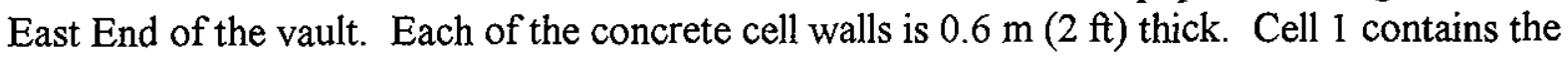
following equipment:

- Tank TK-001,

- Sump jet,

- Wall nozzles,

- Permanent piping,

- Instrumentation, and

- Cell spray system.

2.1.1.1 Cell 1 Sump: The cell sump contains approximately $94 \mathrm{~L}$ ( 25 gal) of liquid that may be drainage from a recent (January 1997) flooding event that was caused by a failed sanitary water line near the facility. The level of the water in the sump is slowly decreasing, which may be attributable to leakage. There is an additional consideration that the increased sump level reading may have been partially attributable to oil leakage into the instrument air lines, which happened at the same time as the flooding event.

2.1.1.2 Tank TK-001: Tank TK-001 contains approximately 379 L (100 gal) of residual sludge from past transfers or transfer line leakage. TK-001 also contains approximately 4,540 L $(1,200 \mathrm{gal})$ of liquid that is believed to be water from past transfer line flushes. No sampling information is available. The tank is equipped with the following:

- Upper and lower cooling coils,

- Transfer pump,

- Transfer jet,

- Agitator,

- Spray rings,

- Purge air system,

- Sampler,

- Vessel vent and chemical addition lines,

- Instrumentation, and

- Three spare tank nozzles. 
2.1.2 Cell 2: The Cell 2 is located between cells 1 and 3 of the canyon building. Cell 2 contains the following equipment:

- Tank TK-002,

- Sump jet,

- Wall nozzles,

- Permanent piping,

- Instrumentation,

- Cell spray system, and

- Radiation monitoring equipment.

2.1.2.1 Cell 2 Sump: The Cell 2 sump contains less than $19 \mathrm{~L}$ ( 5 gal) of liquid. The level of the Cell 2 sump also rose sharply at the time of the flooding event and has since returned to its previous level.

2.1.2.2 Tank TK-002: Tank TK-002 may contain approximately $2,270 \mathrm{~L}$ ( 600 gal) of residual sludge from 241-AX-104. This material may have been transferred into the 244-AR Vault in early 1978. TK-002 also contains about 44,100 L (11,650 gal) of water transferred from TK-004 and past transfer line flushes. Sampling information is available for the 241-AX-104 sludge. The tank is equipped with the following equipment:

- Upper and lower dual service (heating and cooling) coils

- Transfer pump

- Sluice pump

- Transfer jet

- Agitator

- Spray rings

- Purge air system

- Sampler

- Vessel vent and chemical addition lines

- Radiation monitoring dry well

- Instrumentation

- Three spare tank nozzles, and

- Spare permanent piping line

2.1.3 Cell 3: Cell 3 is located on the West End of the canyon building and contains

- Tanks TK-003 and TK-004,

- Sump jet, wall nozzles,

- Permanent piping,

- Instrumentation,

- Cell spray system, and

- Radiation monitoring equipment. 
2.1.3.1 Cell 3 Sump: Cell 3 contains about 12,869 L (3,400 gal) of water (rain and snowmelt) from roof leaks and seal pot overflow. The Cell 3 sump has been completely filled. The sump capacity is only 27 gallons.

2.1.3.2 Tank TK-003: Tank TK-003 contains approximately $190 \mathrm{~L}$ (50 gal) of residual sludge from past transfers. TK-003 also contains about 7,380 L (1,950 gal) of water from the cell sump and past transfer line flushes. No sampling information is available. The tank is equipped with the following equipment:

- Cooling coil,

- Two transfer jets,

- Transfer pump,

- Agitator,

- Spray ring,

- Purge air system,

- Sampler,

- Vessel ventilation and chemical addition lines, and

- Instrumentation, and

- Three spare tank nozzles.

2.1.3.3 Tank TK-004: Tank TK-004 contains about $190 \mathrm{~L}$ ( $50 \mathrm{gal}$ ) of residual sludge from 241-AX-104 and other transfers. TK-004 also contains about $757 \mathrm{~L}$ (200 gal) of water from TK-003 and past transfer line flushes. Sampling information is available for the 241-AX-104 sludge.

Historical information shows that $2,271 \mathrm{~L}$ ( $600 \mathrm{gal})$ of sludge was transferred to TK-004 from 241-AX-104 around late 1977 or early 1978 . There is no actual documentation that says the waste was moved to a different tank. The normal transfer would be to tank TK-002. The weight factor instruments (including manometers readings) indicates that this tank contains only about $946 \mathrm{~L}$ (250-gal) of some something possibly residual sludge from 241-AX-104. Either the sludge was moved or remainder is a tank heel or the sludge has continued to dry over the years to leave 250 gallons of solids or very thick sludge. The tank is equipped with the following components:

- Cooling coil,

- Two transfer jets,

- Transfer pump,

- Agitator,

- Spray ring,

- Purge air system,

- Sampler,

- Vessel ventilation and chemical addition lines, and

- Instrumentation, and

- Three spare tank nozzles. 
2.1.4 Failed Equipment Storage Tubes: The failed equipment storage tubes are believed to be empty, but this cannot be verified. Removal of the cover blocks is necessary to inspect them, but the overhead crane is out of service and the cover blocks cannot be removed.

\subsection{Best Estimate of Radionuclides in 244-AR Vault}

Currently the 244-AR Vault contains 59,806 liters of liquid and sludge in its tanks, and 12,982 liters of liquid and settled particles in its sumps. The inventory is comprised of the following three components and is quantified in table 1.

a) 2,271 liters of liquid waste and sludge in tanks TK-002 and or TK-004. This waste originated from double shell tank 241-AX-104. It was transferred to 244-AR to be used as a radioactive waste sample for waste vitrification studies. The studies were never performed and the waste has been in the tanks since April 1978. This portion of the inventory comprises greater than 99 percent of the curie content in 244-AR Vault. The predominant radionuclides are strontium and yttrium. The inventory was derived from the Best Basis Inventory Estimates for Radioactive Components in 241-AX-104.

b) 56,677 liters of rainwater, steam condensate and raw water pumped from the sumps into the tanks during facility operations. The contribution to the radionuclide inventory of this component of the inventory was not quantified. Its radionuclide content is insignificant in comparison to the waste in tanks TK-002 and TK-004 above. It significantly increased the volume in the tanks but not the radionuclide concentrations.

c) 12,982 liters of rainwater and snow melt currently accumulated in the sumps, and surface contamination residing on the inside of the facility.

\subsection{Facility Walk Down Information}

a) Sump and tank levels: The sampling system has been disabled for about 15 years. Current contents of the tanks are based on process knowledge.

b) Facility Roof Leaks: Roof inspection of canyon building was performed in the mid 1990 's, As a result repair of roof was attempted without success. Roof is still leaking and there are concerns about the water leakage into light fixtures in the operating room of the facility.

c) Water Infiltration into the Facility: The sump levels in the vault cells have increased over time. The tank levels in the cells have remained constant. A possible reason for increasing sump levels may be attributed to oil leakage into the instrument airlines and eventually the cells. There was an activity to jet pump the cell sump contents to tank TK-003. This was unsuccessful. The sump contents need to be removed to avoid damage to the tanks from buoyancy forces. If sump/cell levels continue to rise, there are potential environmental concerns from sump contaminants. 
HNF-4453 Rev. 0

\section{$2.4 \quad$ Facility Occurrences}

The following 244-AR Vault Facility water intrusion occurrences have been reported:

a) PHMC-TANKFARM-1997-0001: On 01/03/97 the liquid level in 244-AR Sump \#1 increased from $3 \%$ to $51.5 \%$. An unusual increase in the outside temperature resulted in a sudden and large amount of snowmelt. In addition to the snowmelt, an above average amount of precipitation fell during this time period. Two paths are available to Cell 1 of the 244-AR vault. The drain line for the concrete encasement line of the 151-AR diversion box. The other path is the drain line located at the bottom of each of the failed equipment storage tubes.

b) PHMC-TANKFARM-1997-0011: On 01/23/1997, An increase in the level of 244-AR Sump \#2 occurred due to the intrusion of water from a ruptured sanitary water lines outside the facility. Two water lines broke outside the 244-AR Vault Facility. Water flowed toward the facility, entered the control room, flowed around the northeast side of the facility and entered the ground near the seal pot manhole. Current drawings do not show a potential leak path, but the rapid rise in the sump level was concurrent with the water line breakage.

c) PHMC-TANKFARM-1997-0037: On 04/07/1997 an unexplained decrease in 244-AR Sump \#2 level was observed. The surface level in the 244-AR decreased 2.57 inches in 4 weeks. Cause of decrease in water level is unknown. 


\section{Figure 2-1. 244-AR Vault Facility Schematic}

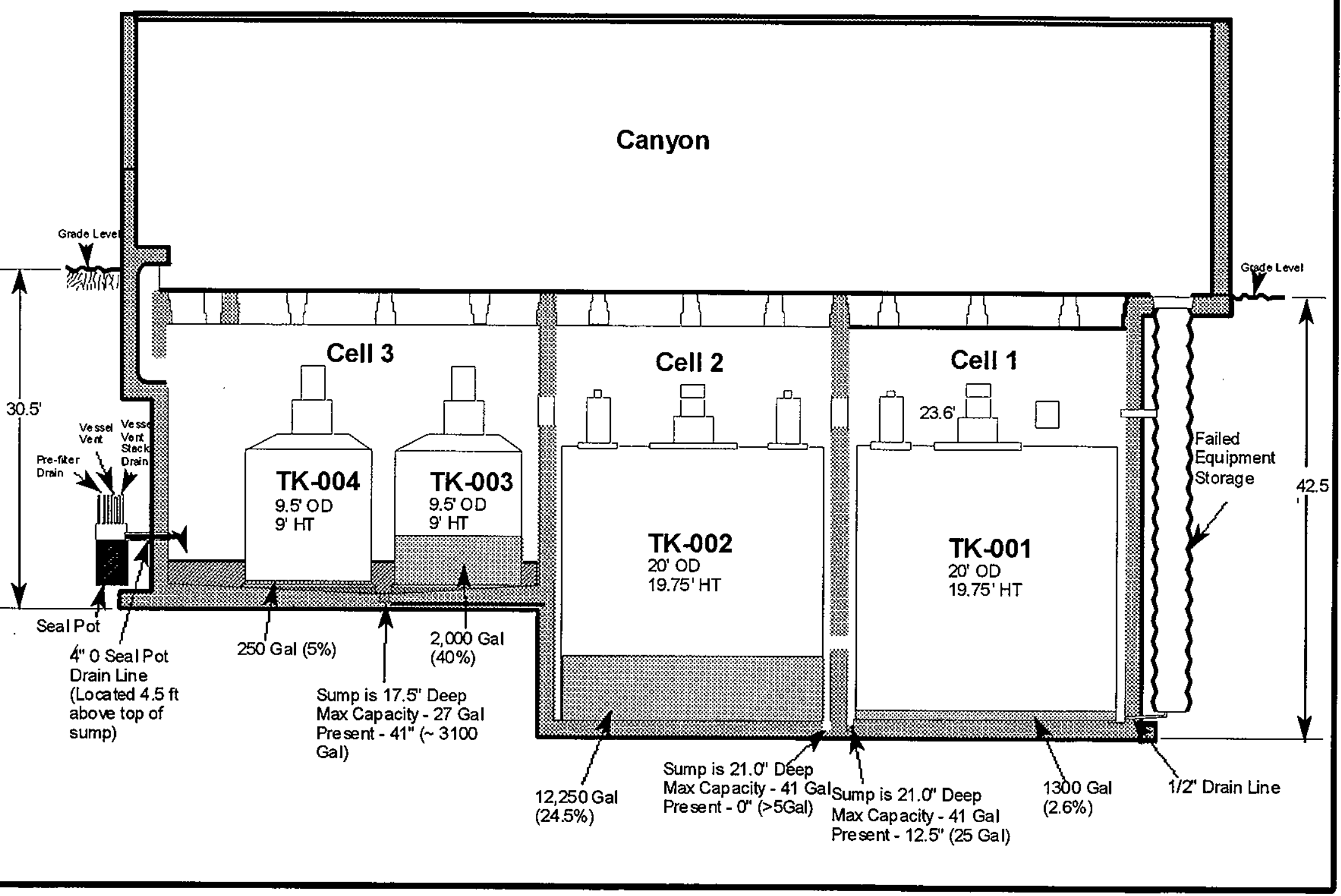


HNF-4453 Rev. 0

This page intentionally left blank 


\subsection{HAZARD IDENTIFICATION AND EVALUATION}

The hazard identification and evaluation for the 244-AR Vault (flooding) used the Hazards and Operability Analysis (HAZOP) method. In a HAZOP, a team leader systematically guides the HAZOP team through the system/process being evaluated using a fixed set of process parameters (e.g., flow, temperature, pressure) and guide words (e.g., high, low, less, more). The combination of the process parameters and guide words are applied at specific points or "nodes" in the system design to identify potential hazardous conditions associated with the operation of the system.

The waste transfer HAZOP was performed by an interdisciplinary team to identify the combinations of process parameters and guide words (the combination is generally referred to as deviations) associated with the installation and operation of waste transfer equipment that could potentially result in undesirable consequences. Process parameters, guide words, and deviations are listed in Table 3-1. During the HAZOP process potential consequences of the deviations were estimated, hazardous conditions formulated, and possible corrective and/or preventive measures identified and discussed. This process is recognized by the American Institute of Chemical Engineers (AIChE) and is described in AIChE, 1992, Guidelines for Hazard Evaluation Procedures. The HAZOP uses a tabular format to record the results of the systematic process.

Because the HAZOP process tends to be qualitative in nature, the expertise and experience of the team is of primary importance in establishing the credibility of the analysis. A short resume of each team member is included in Appendix A to document the expertise and experience level of each team member.

\subsection{Methodology}

The HAZOP team met to develop the raw data. The information was recorded systematically in tabular format. The following sections describe the HAZOP table structure, information recording details, and process node descriptions.

\subsubsection{HAZOP Table}

The HAZOP table (Appendix B, Table B1) was structured to ensure a systematic and thorough evaluation of the potential hazards. The HAZOP table captured the following information:

Node Description: This provides a description of the node being evaluated. This information is captured in the table row preceding the first item for a given node, and is summarized in Section 3.1.2.

Item ID: The item identification (ID) used to record a unique identifier for the hazardous condition. 
Node: Specific point in the system or process where the deviation from the desired condition of a process variable is evaluated. Nodes are chosen to ensure that every area where an undesirable condition could occur is evaluated.

Process Variable: The characteristics of a process, such as flow, pressure, or temperature, which are used to define proper operation.

Guide Word: Words that describe the variance in the process variable of concern such as high, low, more, or less. A complete summary of variables and guide words is given in Table 3-1.

Possible Causes of Deviation: The causes of the deviation (combination of process variable and guideword) that leads to the hazardous condition. Identifying causes is important to identifying potential preventive or mitigative controls or features for significant hazardous conditions as well as potential consequences. In many cases, multiple hardware or operational faults are required to produce a hazardous condition. This column identifies the sequence of hardware and operational faults required for the postulated hazardous condition to occur.

Hazardous Condition: The hardware failures, operational faults, or conditions that could result in undesired consequences during waste transfer activities. The hazardous condition is a concise statement combining the Cause, Consequence, and mode of radioactive material release.

Consequence: The potential consequences that could result from the postulated deviation.

Potential SSCs: Structures, systems, and components are existing engineered features (hardware items) identified by the HAZOP team that have the potential to mitigate or prevent the hazardous condition of concern. The engineered features are candidates for designation as Safety Significant items for hazardous conditions that pose a significant threat to the health of facility workers and onsite personnel or Safety Class for hazards that pose a significant threat to offsite individuals. No attempt is made to provide an exhaustive list of SSCs. The intent of this column is to stimulate discussion among the HAZOP team members. These items should not be construed as being the "official" controls that would eventually be credited in the AB.

Potential TSRs: Technical Safety Requirements are controls identified by the HAZOP team that have the potential to mitigate or prevent the hazardous condition of concern. Included under the TSR designation are also other potential administrative controls. No attempt is made to stimulate discussion among the HAZOP team members. These items should not be construed as being the "official" administrative features that would eventually be credited in the $\mathrm{AB}$.

Con Cat: The consequence category is a code designator for the level of consequence associated with a hazardous condition. The consequence ranking is a "first cut," qualitative 
estimate of the consequence of the hazardous condition being evaluated. It is evaluated assuming no controls are present. The following system of designators is used:

S0 Negligible safety concerns for the facility worker.

S1 Potential industrial injury, low radiological or chemical exposure dose consequences to the facility worker.

S2 Potential significant radiological dose consequences or chemical exposure to onsite workers located outside the facility.

S3 Potential significant radiological dose consequences or chemical exposure to the offsite population.

Freq Cat: The frequency category is a "first cut," qualitative estimate of the likelihood of the hazardous condition assuming no controls are present. The following system is used:

F3 Events that are expected to occur one or more times during the lifetime of the facility, categorized as "anticipated" events. The frequency range associated with this category is $1 \mathrm{E}-02 / \mathrm{yr}$ to $0.1 / \mathrm{yr}$.

F2 Events that could occur during the lifetime of the facility, but with low probability. Such events are categorized as "unlikely" and fall in the range of $1 \mathrm{E}-04 / \mathrm{yr}$ to $1 \mathrm{E}-02 / \mathrm{yr}$.

F1 Events not expected to occur during the lifetime of the facility, categorized as "extremely unlikely." The frequency range associated with this category is $1 \mathrm{E}-06 / \mathrm{yr}$ to $1 \mathrm{E}-04 / \mathrm{yr}$.

F0 Events categorized as "beyond extremely unlikely," with a frequency less than $1 \mathrm{E}-06 / \mathrm{yr}$. Events in this category (such as meteor strike) are so unlikely they generally do not require special controls.

Env Cat: The environmental consequence ranking is a "first cut," qualitative estimate of the environmental severity of the hazardous condition assuming no controls are present. The following system is used

E0 No significant environmental effect outside the facility confinement systems

E1 Limited environmental discharge of hazardous material outside the facility.

E2 Large environmental discharge of hazardous material within the plant site boundary.

E3 Significant environmental discharges of hazardous material outside the plant site boundary. 
Remarks: Miscellaneous observations or clarifying comments for a given item.

Nomenclatures used in Appendix B, Tables B-2, B-3, and B-4 are consistent with the preceding descriptions.

The following additional nomenclatures are used in Table B-5, Appendix B:

- Potential Preventive SSC - SSCs from the analyzed accident in the AB, determined by this hazards analysis to apply to the hazardous condition, that provide a preventive function.

- Potential Preventive TSR - TSRs from the analyzed accident in the $\mathrm{AB}$, determined by this hazards analysis to apply to the hazardous condition, that provide a preventive function.

- Potential Mitigative SSC - SSCs from the analyzed accident in the AB, determined by this hazards analysis to apply to the hazardous condition, that provide a mitigative function.

- Potential Mitigative TSR - TSRs from the analyzed accident in the AB, determined by this hazards analysis to apply to the hazardous condition, that provide a mitigative function.

The following nomenclature was obtained from HNF-SD-WM-TI-764 and used in Tables B-5 and B-6 of Appendix B:

- BIN - A code that describes the release attributes for high safety consequence (S2 and S3) and worker hazard (S1) with anticipated frequency (F3) hazardous condition.

- Cause Grp - Cause Group - An alpha/numeric code used to permit sorting of data by the cause of a hazardous condition.

- MAR - Material at Risk - A description of the type and quantity (when applicable) of material that may be affected by the occurrence of a hazardous condition

- Rep Acc - Representative Accident - An alpha/numeric code used to specify the analyzed accident by which the specified hazardous condition is represented. Only hazardous conditions with high safety consequence (S2 or S3) are assigned representative accidents.

\subsubsection{HAZOP Node Description}

The 244-AR HAZOP was based on nodes chosen to capture points in the process where deviations could result in significant consequences. The node definitions presented below were used in the 244-AR HAZOP for vault flooding: 
- Node 1: Cell 3 including TK-003 and TK-004

- Node 2: Cell 2 including TK-002

- Node 3: Cell 1 including TK-001

- Node 4: Failed Equipment Storage Tubes

- Node 5: Seal Pot Pit

The location of the nodes is shown on the 244-AR Vault HAZOP Node diagram, Figure 3-1.

\subsection{Assumptions}

During the hazard identification/evaluation team meeting certain assumptions were made about the 244-AR Vault Facility, which are unique to this HAZOP and hazard analysis:

1. The important features of 244-AR vault are captured in the 244-AR Vault Facility Schematic, Figure 2-1 of the preceding section.

2. The existing AB Hazard Analysis except for the flooding of the 244-AR vault cells adequately addresses hazardous conditions associated with the 244-AR Vault Facility. The intent of this HAZOP was to identify the hazardous conditions related to the flooding of the vault cells of the 244-AR Vault Facility.

3. The contents of the failed equipment storage tubes were unknown at the time the HAZOP was conducted for the 244-AR Vault Facility.

\subsection{Evaluation}

This document is not part of the TWRS $A B$, it is only intended to identify and categorize hazardous conditions associated with the 244-AR Vault Facility under flood conditions.

Thirty-four hazardous conditions were identified as a result of the HAZOP process and are shown in Table B1, Appendix B. The hazardous conditions developed during the HAZOP were only for flooding of the vault cells. The hazardous conditions are sorted with respect to the five nodes listed in Section 3.1 and shown in Figure 3-1.

Of the thirty-four hazardous conditions, thirteen were assigned S2 or S3 consequences. All of the S2 and S3 hazardous conditions were found to have characteristics similar to one of the Representative Accidents of the TWRS BIO. The representative accident is "Surface Leak Resulting in Pool" with an assigned Rep Acc number of 26. The definition of the 
representative accident is provided in Table B6, Appendix B. Hazardous condition frequency was not considered in assigning a particular hazardous condition to a Representative Accident.

Tables B2, B3, and B4 of Appendix B present the hazardous conditions grouped by consequence category ( $\mathrm{S} 3, \mathrm{~S} 2$, and $\mathrm{S} 0$ respectively). There were no $\mathrm{S} 1$ hazardous conditions identified in the HAZOP. These three tables contain the Item ID, Cause, Hazardous Condition, Frequency Category without controls (Freq Cat), and the Environmental Impact Category (Env Cat).

Table B5, Appendix B, is a presentation of the potential applicability of current TWRS AB controls to hazardous conditions with S2 or S3 consequences. This table contains the Item ID, MAR, Cause, Hazardous Condition, Potential Preventive SSC, Potential Preventive TSR, Potential Mitigative SSC, Potential Mitigative TSR, Remarks, Con Cat, and Freq Cat. The table demonstrates that potential controls for prevention or mitigation of the identified hazardous conditions exist in the TWRS AB. The purpose of Table B5 is to show whether potential controls for prevention or mitigation of the identified hazardous conditions do exist in the TWRS AB. The specified controls are not to be construed as the approved set of controls for the particular hazardous condition. Designation of the approved set of controls is outside the scope of this hazard analysis report.

Evaluation of the thirteen hazardous conditions in the S2 and S3 consequence categories resulted in the following concerns being identified which may need to be addressed via TSRs:

- There are no surveillance controls for the 244-AR Vault Facility,

- There is no recovery or emergency plan for the hazardous conditions identified.

- There is a potential for leakage of contaminated liquid from the 244-AR Vault Facility into the subsurface soil.

It appears there are no established mitigative or preventive TSRs for the 244-AR Vault Facility to adequately address these identified hazardous conditions and concerns.

The thirteen hazardous conditions fall under the general category of a "Surface Leak Resulting in Pool". All thirteen hazardous conditions were associated with leaks that spill onto the ground surface resulting in a pool of liquid waste. Table B6, Appendix B, shows these hazardous conditions grouped under the Representative Accident 26 . There are six hazardous conditions assigned to the $\mathrm{S} 3$ consequence category. The remaining seven hazardous conditions are assigned to the $\mathrm{S} 2$ consequence category. The identifiers for these hazardous conditions are:

- S3 Hazardous Conditions

- 244AR-New.05,

- 244AR-New.06,

- 244AR-New.15,

- 244AR-New.16,

- 244AR-New.24, and

- 244AR-New.25 
HNF-4453 Rev. 0

- S2 Hazardous Conditions

- 244AR-New.03,

- 244AR-New.04,

- 244AR-New.07,

- 244AR-New.13,

- 244AR-New.14,

- 244AR-New.22, and

- 244AR-New.23.

The six hazardous conditions having a consequence ranking of $\mathrm{S} 3$ all have a frequency ranking of F0. This ranking is defined as "beyond extremely unlikely". All of these hazardous conditions are caused by the intrusion of water into of the vault cells of the 244-AR Vault Facility resulting in the complete filling of all three cells of the facility. The tanks in each of the cells become dislodged and rupture, spilling their contents. The contents eventually escape the vault cells as water intrusion continues resulting in a liquid pool outside the facility.

The seven hazardous conditions assigned a consequence ranking of S2 have a frequency ranking of F1, which is defined as "extremely unlikely". All of these hazardous conditions are the result of water intrusion into one of the cells of the 244-AR Vault Facility resulting in the complete filling of all three cells of the facility. The tanks in each of the cells are postulated not to rupture under these conditions. Contamination within the cells is released to the ground surface via overflow of cells from continued water intrusion and release of a pool of liquid outside of the facility.

Table B6, Appendix B, presents the S2 and S3 category hazardous conditions grouped under the applicable BIO Accident Analysis Section. This table contains the Bin, Item ID, MAR, Hazardous Condition, Cause, Frequency Category, Consequence Category, Cause Group Code, and Representative Accident designator. The table is intended to provide objective evidence whether a specific Representative Accident can represent a hazardous condition. If a hazardous condition cannot be assigned to a Representative Accident, then further detailed analysis is required to determine if a new Representative Accident category needs to be developed. The Representative Accident descriptions from the BIO accident analyses are shown for comparison purposes as shaded rows in Table B6 of Appendix B.

The one Representative Accident used from the BIO accident analyses is shown as a shaded row in Table B6. All of the S2 and S3 ranked hazardous conditions of the 244-AR Vault HAZOP are covered by the Representative Accident "Surface Leak Resulting in Pool" of the BIO Accident Analysis Section 5.3.2.18. 
Table 3-1. HAZOP Process Variables and Guide Words - Deviations

\begin{tabular}{|c|c|c|c|c|c|c|c|}
\hline \multirow[b]{2}{*}{$\begin{array}{l}\text { Process } \\
\text { Variables }\end{array}$} & \multicolumn{7}{|c|}{ Guide Words } \\
\hline & $\begin{array}{l}\text { NO, } \\
\text { NOT, } \\
\text { NONE }\end{array}$ & $\begin{array}{l}\text { LESS, } \\
\text { LOW, } \\
\text { SHORT }\end{array}$ & $\begin{array}{l}\text { MORE, } \\
\text { HIGH, } \\
\text { LONG }\end{array}$ & PART OF & $\begin{array}{l}\text { AS WELL AS, } \\
\text { ALSO }\end{array}$ & OTHER THAN & REVERSE \\
\hline FLOW & No Flow & $\begin{array}{l}\text { Low Rate, } \\
\text { Low Total }\end{array}$ & $\begin{array}{l}\text { High Rate, } \\
\text { High Total }\end{array}$ & Missing Ingredient & $\begin{array}{l}\text { Misdirection, } \\
\text { Impurities }\end{array}$ & Wrong Material & Backflow \\
\hline PRESSURE & Open to Atmosphere & Low Pressure & High Pressure & . & & & Vacuum \\
\hline TEMPERATURE & Freezing & Low Temperature & High Temperature & & & & Auto-refrigeration \\
\hline LEVEL & Empty & Low Level & High Level & Low Interface & High Interface & & \\
\hline AGITATION & No Mixing & Poor Mixing & Excessive Mixing & Mixing Interruption & Foaming & & Phase Separation \\
\hline REACTION & No Reaction & Slow Reaction & Runaway Reaction & Partial Reaction & Side Reaction & Wrong Reaction & Decomposition \\
\hline TIME PROCEDURE & $\begin{array}{l}\text { Skipped or missing } \\
\text { Step }\end{array}$ & $\begin{array}{l}\text { Too Short, } \\
\text { Too Little }\end{array}$ & $\begin{array}{l}\text { Too Long, } \\
\text { Too Much }\end{array}$ & Action(s) Skipped & $\begin{array}{l}\text { Extra Action(s) } \\
\text { (Shortcuts) }\end{array}$ & Wrong Action & $\begin{array}{l}\text { Out of Order, } \\
\text { Opposite }\end{array}$ \\
\hline SPEED & Stopped & Too Slow & Too Fast & Out of Sync & & Web or Belt Break & Backward \\
\hline PH & & Low $\mathrm{pH}$ & High $\mathrm{pH}$ & & $\begin{array}{l}\text { Additional Acid, } \\
\text { Additional Base }\end{array}$ & $\begin{array}{l}\text { Wrong Acid, } \\
\text { Wrong Base }\end{array}$ & \\
\hline CONCENTRATION & & Low Concentration & High Concentration & Missing Ingredient & & $\begin{array}{l}\text { Additional } \\
\text { Ingredient }\end{array}$ & \\
\hline VISCOSITY & & Low Viscosity & High Viscosity & & & & \\
\hline VOLTAGE & No Voltage & Voltage Low & Voltage High & Wrong Waveform & Interference Voltage & $\begin{array}{l}\text { Wrong Frequency, } \\
A C \text { instead of } D C \\
D C \text { instead of } A C\end{array}$ & Wrong Polarity \\
\hline CURRENT & No Current & Current High & Current Low & & & Current Fluctuating & Wrong Polarity \\
\hline STATIC & & & Static Charge & & & & \\
\hline SPECIAL & Utility Failure & External Leak & External Rupture & Tube Leak & Tube Rupture & $\begin{array}{l}\text { Startup, } \\
\text { Shutdown, } \\
\text { Maintenance }\end{array}$ & \\
\hline $\begin{array}{l}\text { STRUCTURAL } \\
\text { STRENGTH }\end{array}$ & Structural Failure & Less Strength & More Strength & & & & \\
\hline SHIELDING & & Less Shielding & More Shielding & & & & \\
\hline
\end{tabular}




\section{Figure 3-1. 244-AR Vault Facility HazOp Node Diagram}

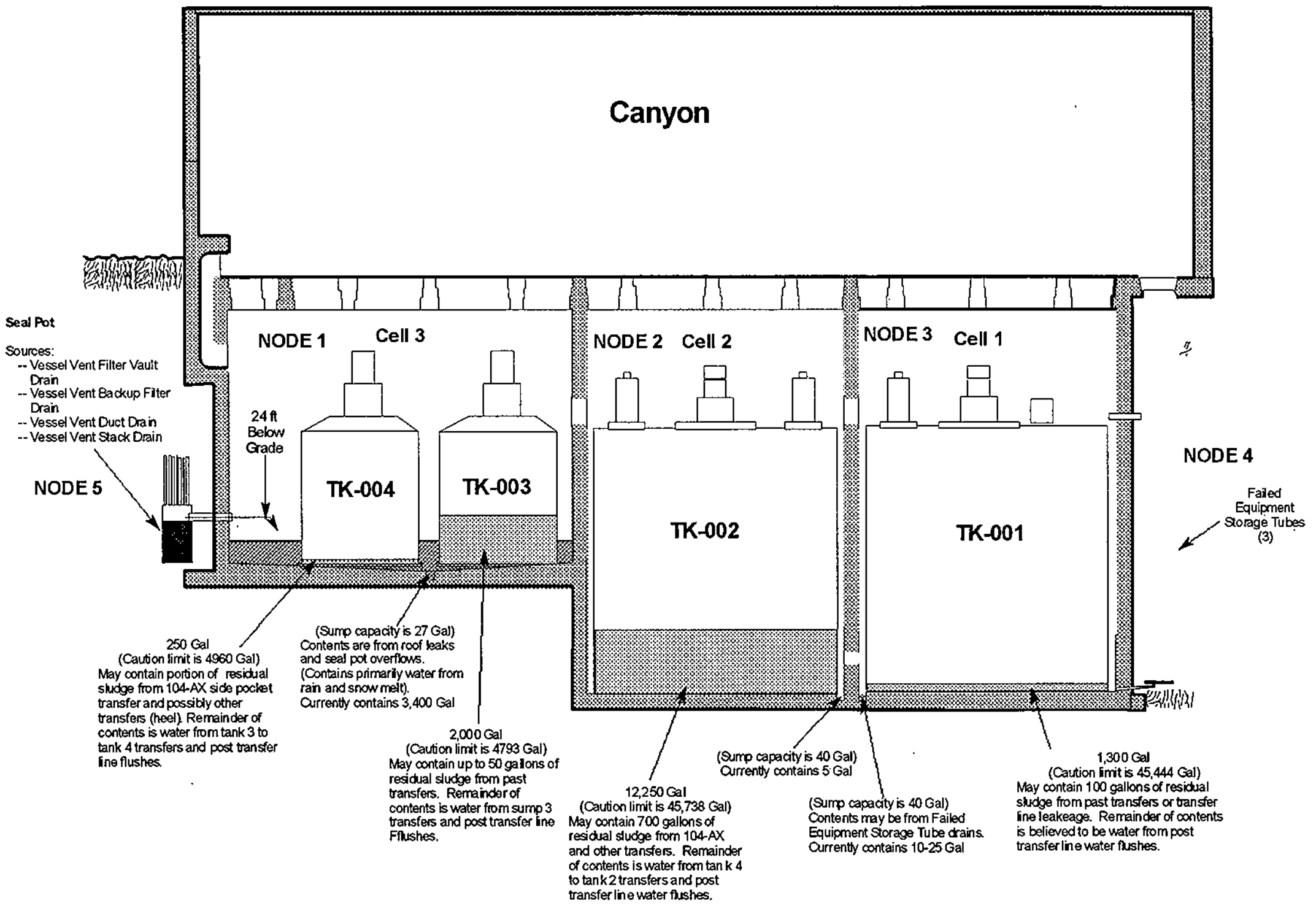


HNF-4453 Rev. 0

This page intentionally left blank 


\subsection{CONCLUSIONS}

The 244-AR Vault Facility supplemental HAZOP identified 13 hazardous conditions having S2 or S3 consequences. These hazardous conditions fit into one of the TWRS BIO Accident categories as shown in Table B6, Appendix B. All identified hazardous conditions were judged to be bounded by the Representative Accident, Surface Leak Resulting in Pool, in the current TWRS AB. The following concerns were identified as a result of this 244-AR vault hazard analysis:

- There are no surveillance controls for the 244-AR Vault Facility,

- There is no recovery or emergency plan for the hazardous conditions identified.

- There is a potential for leakage of contaminated liquid from the 244-AR Vault Facility into the subsurface soil causing only environmental consequences.

It appears there are no established mitigative or preventive TSR's for the 244-AR Vault Facility to adequately address these identified hazardous conditions and concerns. 
HNF-4453 Rev. 0

This page intentionally left blank 


\subsection{REFERENCES}

AIChE, 1992, Guidelines for Hazard Evaluation Procedures, American Institute of Chemical Engineers, New York, New York.

HNF-SD-WM-BIO-001, 1999, Tank Waste Remediation System Basis for Interim Operation, Rev. 1, Fluor Daniel Hanford, Inc., Richland, Washington.

HNF-SD-WM-TI-764, 1996, Hazard Analysis Database Report, Rev. 0, Fluor Daniel Hanford, Inc., Richland, Washington.

HNF-SD-WM-TSR-006, 1999, Tank Waste Remediation System Technical Safety Requirements, Rev. 0-Q, Fluor Daniel Hanford, Inc., Richland, Washington.

HNF-2503, Rev. 0, 1998, Authorization Basis Status Report (Miscellaneous TWRS Facilities, Tanks and Components), R. G. Stickney, DESH, Richland, Washington. 
HNF-4453 Rev. 0

This page intentionally left blank 
HNF-4453 Rev. 0

Appendix A

\section{HAZOP Team Biographical Information}




\section{HAZOP Team Biographical Information}

John W. Bloom - DE\&S Hanford - Senior Licensing Engineer. Mr. Bloom has more than 22 years experience in the nuclear industry with 19+ years at Hanford. His experience includes management positions in operations, production control, independent oversight, S/RDS development, and 1-1/2 years on the BIO/FSAR development team in a lead position. He was the safety lead for the Hanford Tanks Initiative project for two years. He holds bachelor and masters degrees in chemistry.

David J. Braun - Fluor Daniel Northwest Inc - Engineer - Safety Analysis and Risk Assessment $\underline{\mathrm{PE}}$. Mr. Braun has over 22 years experience at Hanford working primarily in Safety Analysis. His experience includes Probabilistic Risk Analysis of nuclear reactors, tank farm activities, and hazards identification and evaluation of various Hanford site operations and facilities. He was one of the lead engineers on the hazards identification and evaluation team for the current TWRS BIO and draft FSAR. He has facilitated numerous PHA and HAZOP studies for projects at the Hanford site Mr. Braun has a Master of Science Degree in Mechanical Engineering from the University of California at Davis. He is a registered Professional Engineer in Mechanical Engineering (Washington State).

Sohan S. Gahir - B.S. Mechanical Engineering, MS Industrial Engineering, Licensed Professional Engineer in the state of Washington and Pennsylvania. TWRS Licensing engineer for the retrieval projects. Thirty-six assignments at commercial power plants and at the Hanford Nuclear Reservation in engineering positions. His experience includes design engineering, Preliminary Safety Evaluation development, Safety Analysis Report development, inactive miscellaneous storage facility risk evaluation, TWRS BIO implementation, seismic upgrades at 100-N area, barrier doors design and installation at 100K, WRAP facility SAR review, and many other projects at the Hanford Site

William H. Grams - B.S. Mining Engineering; M.S. Mechanical Engineering. Experience includes: Licensing engineer for TWRS, development and implementing Authorization Basis licensing strategies for new waste retrieval equipment and processes, preparation of Unreviewed Safety Question documentation, development and implementation of a low-level waste certification program including conduct of waste management audits, review and approval of certification plans, and direct assistance to waste generators; preparation of waste management disposal instructions including characterization requirements, packaging specifications, regulatory requirements; and evaluation and characterization of low-level waste streams.

Terance Laney - B.S. Mechanical Engineering. Cognizant Engineer and Design Authority for the 244-AR Vault. More than 18 years experience in a broad range of engineering and technical assignments with 7 years at the Hanford Site. Experience includes Systems Engineering, Interface Control, Production/Manufacturing Engineering, Configuration Management, and lead Engineer for various 244-AR Vault technical activities. 
HNF-4453 Rev. 0

Milton V. Shultz, Jr. - B.S. Nuclear Engineering Technology. Facilitator for Tank 241-SY-101 waste transfer HAZOP. More than twenty-four years experience in a broad range of engineering and technical assignments at the Hanford Site. Experience includes leading Preliminary Hazards Analysis (PHAs) and HAZOPs for a variety of TWRS projects, including several for the TWRS FSAR and BIO efforts, contributor to the hazards analysis work for the TWRS BIO. Has performed independent Nuclear Safety evaluations of reactor plant design and operation at Hanford's N Reactor. 
HNF-4453 Rev. 0

This page intentionally left blank. 
HNF-4453 Rev. 0

Appendix B

Hazard Evaluation Tables

B-1 
HNF-4453 Rev. 0

This page intentionally left blank

B-2 
Appendix B Table of Contents

Table B1. HAZOP Table - 244-AR Vault Facility

Table B2. Hazardous Conditions With Potential Significant Offsite Consequences (S3) ...23

Table B3. Hazardous Conditions With Potential Significant Onsite Consequences (S2) ...25

Table B4. Hazardous Conditions With No Significant Consequences (S0)

Table B5. Controls From BIO SSCs and TSRs That Potentially Address Hazardous Conditions For 244-AR With Potential S3 and S2 Consequences.

Table B6. S2 and S3 Hazardous Conditions Sequenced By BIO Accident Section. 36 
HNF-4453 Rev. 0

This page intentionally left blank

B-4 
Table B1. HAZOP Table - 244-AR Vault Facility

\begin{tabular}{|c|c|c|c|c|c|c|c|c|c|c|c|c|}
\hline Item ID & Node & $\begin{array}{l}\text { Process } \\
\text { Variable }\end{array}$ & $\begin{array}{l}\text { Guide } \\
\text { Word }\end{array}$ & $\begin{array}{c}\text { Possible Causes } \\
\text { of Deviation }\end{array}$ & Consequence & $\begin{array}{l}\text { Hazardous } \\
\text { Condition }\end{array}$ & $\begin{array}{l}\text { Potential } \\
\text { SSCs }\end{array}$ & $\begin{array}{l}\text { Potential } \\
\text { TSRs }\end{array}$ & $\begin{array}{l}\text { Con } \\
\text { Cat }\end{array}$ & $\begin{array}{c}\text { Freq } \\
\text { Cat }\end{array}$ & $\begin{array}{l}\text { Env } \\
\text { Cat }\end{array}$ & Remarks \\
\hline \multicolumn{13}{|c|}{ Node 1 - Cell 3 including TK-003 and TK-004 } \\
\hline 244AR-New.01 & 1 & Temperature & Low & $\begin{array}{l}\text { Not considered a } \\
\text { problem - below } \\
\text { ground conditions } \\
\text { maintain constant } \\
\text { temperature - } \\
\text { there is no active } \\
\text { ventilation to } \\
244-A R \text { Cell } 3\end{array}$ & None & None & None & None & N/A & $N / A$ & N/A & $\begin{array}{l}\text { Cell } 1, \text { Cell } 2 \text { and Failed } \\
\text { Equipment Storage Tube } \\
\text { same as Cell } 3 \text { for this } \\
\text { condition }\end{array}$ \\
\hline 244AR-New.02 & 1 & Level & $\begin{array}{l}\text { Low/ } \\
\text { No }\end{array}$ & $\begin{array}{l}\text { Desired Condition } \\
\text { of } 244-A R \text { Cell } 3\end{array}$ & None & None & None & None & N/A & $N / A$ & N/A & $\begin{array}{l}\text { Material dry out and } \\
\text { resuspension is not } \\
\text { considered a concern } \\
\text { because no active ventilation } \\
\text { in } 244-A R \text { facility }\end{array}$ \\
\hline 244AR-New.03 & 1 & Level & High & $\begin{array}{l}\text { General Intrusion: } \\
\text { Water line } \\
\text { ruptures Snow, } \\
\text { Rain }\end{array}$ & $\begin{array}{l}\text { Water intrusion } \\
\text { into } 244 \text { AR } \\
\text { Cell } 3 \text { with } \\
\text { potential } \\
\text { movement of } \\
\text { radioactive } \\
\text { contamination in } \\
\text { cell to soil } \\
\text { through cell } \\
\text { leaks } \\
\text { Potential for } \\
\text { floating tanks in } \\
244 \text { AR Cell } 3 \\
\text { Spill of } \\
\text { radioactive } \\
\text { waste to the cell } \\
\text { due to rupture of } \\
\text { tank, leak of } \\
\text { radiological } \\
\text { material to soil } \\
\text { Potential for pool } \\
\text { leak if cells } \\
\text { overflow }\end{array}$ & $\begin{array}{l}\text { Release of } \\
\text { radioactive } \\
\text { contaminated } \\
\text { water to soil } \\
\text { (subsurface) } \\
\text { from 244-AR } \\
\text { Cell } 3 \text { via vault } \\
\text { leaks due to } \\
\text { water leak into } \\
\text { cells } \\
\text { Release of } \\
\text { radioactive } \\
\text { contaminated } \\
\text { water to } \\
\text { ground surface } \\
\text { (pool leak) } \\
\text { from } 244-A R \\
\text { Cell } 3 \text { due to } \\
\text { vault over flow }\end{array}$ & $\begin{array}{l}\text { Service } \\
\text { water flow } \\
\text { totalizers } \\
\text { Weight } \\
\text { factor level } \\
\text { alarms }\end{array}$ & $\begin{array}{l}\text { AC: Fill } \\
\text { tanks to } \\
\text { prevent } \\
\text { turnover if } \\
\text { intrusion } \\
\text { can't be } \\
\text { stopped } \\
\text { (piping is } \\
\text { present) } \\
\text { AC: } \\
\text { Monitor } \\
\text { sump level } \\
\text { AC: } \\
\text { Service } \\
\text { water } \\
\text { monitoring }\end{array}$ & S2 & F1 & E2 & $\begin{array}{l}\text { Tank connections are on top } \\
\text { of tank } \\
\text { Tanks may turn over if they } \\
\text { are top-heavy in Cell } 3 \\
\text { There is no current } \\
\text { mechanism to empty sump or } \\
\text { tanks } \\
\text { Ventilation system not } \\
\text { operational } \\
244-A R \text { crane not operational } \\
\text { No steam supply available } \\
\text { Service water is isolated from } \\
244-A R \\
\text { Longitudinal crack from Cell } 3 \\
\text { to Cell } 2 \text { (status unknown) } \\
\text { Cell interconnection in facility } \\
\text { creates situation where all } \\
\text { cells must fill after a certain } \\
\text { level is reached in a particular } \\
\text { cell }\end{array}$ \\
\hline
\end{tabular}


Table B1. HAZOP Table - 244-AR Vault Facility

\begin{tabular}{|c|c|c|c|c|c|c|c|c|c|c|c|c|}
\hline Item ID & Node & $\begin{array}{c}\text { Process } \\
\text { Variable } \\
\end{array}$ & $\begin{array}{l}\text { Guide } \\
\text { Word }\end{array}$ & $\begin{array}{c}\text { Possible Causes } \\
\text { of Deviation }\end{array}$ & Consequence & $\begin{array}{c}\text { Hazardous } \\
\text { Condition }\end{array}$ & $\begin{array}{c}\text { Potential } \\
\text { SSCs } \\
\end{array}$ & $\begin{array}{c}\text { Potential } \\
\text { TSRs }\end{array}$ & $\begin{array}{l}\text { Con } \\
\text { Cat } \\
\end{array}$ & $\begin{array}{c}\text { Freq } \\
\text { Cat }\end{array}$ & $\begin{array}{l}\text { Env } \\
\text { Cat }\end{array}$ & Remarks \\
\hline 244AR-New.04 & 1 & Level & High & $\begin{array}{l}\text { Roof leaks over } \\
\text { 244-AR Cell } 3\end{array}$ & $\begin{array}{l}\text { Water intrusion } \\
\text { into } 244 \text {-AR } \\
\text { Cell } 3 \text { with } \\
\text { potential } \\
\text { movement of } \\
\text { radioactive } \\
\text { contamination in } \\
\text { cell to soil } \\
\text { through cell } \\
\text { leaks } \\
\text { Potential for } \\
\text { floating tanks in } \\
244-A R \text { Cell } 3 \\
\text { Spill of } \\
\text { radioactive } \\
\text { waste to the cell } \\
\text { due to rupture of } \\
\text { tank, leak of } \\
\text { radiological } \\
\text { material to soil } \\
\text { Potential for pool } \\
\text { leak if cells } \\
\text { overflow }\end{array}$ & $\begin{array}{l}\text { Release of } \\
\text { radioactive } \\
\text { contaminated } \\
\text { water to soil } \\
\text { (subsurface) } \\
\text { from } 244 \text { AR } \\
\text { Cell } 3 \text { via vault } \\
\text { leaks } \\
\text { Release of } \\
\text { radioactive } \\
\text { contaminated } \\
\text { water to } \\
\text { ground surface } \\
\text { (pool leak) } \\
244 \text { AR Cell } 3 \\
\text { due to vault } \\
\text { over flow }\end{array}$ & $\begin{array}{l}\text { Weight } \\
\text { factor level } \\
\text { alarms }\end{array}$ & $\begin{array}{l}\text { AC: Fill } \\
\text { tanks to } \\
\text { prevent } \\
\text { turnover if } \\
\text { intrusion } \\
\text { can't be } \\
\text { stopped } \\
\text { (piping is } \\
\text { present) } \\
\text { AC: } \\
\text { Monitor } \\
\text { sump level }\end{array}$ & s2 & F1 & E2 & $\begin{array}{l}\text { Tank connections are on top } \\
\text { of tank } \\
\text { Tanks may turn over if they } \\
\text { are top-heavy in Cell } 3 \\
\text { There is no current } \\
\text { mechanism to empty sump or } \\
\text { tanks } \\
\text { Ventilation system not } \\
\text { operational } \\
244 \text {-AR crane not operational } \\
\text { No steam supply available } \\
\text { Longitudinal crack from Cell } 3 \\
\text { to Cell } 2 \text { (status unknown) } \\
\text { Cell interconnection in facility } \\
\text { creates situation where all } \\
\text { cells must fill after a certain } \\
\text { level is reached in a particular } \\
\text { cell }\end{array}$ \\
\hline 244AR-New.05 & 1 & Level & High & $\begin{array}{l}\text { Waste } \\
\text { mistransfers }\end{array}$ & $\begin{array}{l}\text { Aerosol release } \\
\text { from pool leak } \\
\text { Radioactive } \\
\text { liquid release to } \\
\text { soil from pool } \\
\text { leak }\end{array}$ & $\begin{array}{l}\text { Release of } \\
\text { radioactive } \\
\text { tank waste } \\
\text { from 244-AR } \\
\text { Cell } 3 \text { to soil } \\
\text { surface (pool } \\
\text { leak) due to a } \\
\text { waste } \\
\text { mistransfer } \\
\text { through } \\
\text { diversion box } \\
241-A R-151\end{array}$ & $\begin{array}{l}\text { Leak } \\
\text { detectors }\end{array}$ & $\begin{array}{l}\text { AC: } \\
\text { Transfer } \\
\text { controls } \\
\text { interconne } \\
\text { cted } \\
\text { facilities } \\
\text { verification } \\
\text { requiremen } \\
\text { t } \\
\text { AC: } \\
\text { Transfer } \\
\text { controls } \\
\text { material } \\
\text { balance }\end{array}$ & \$3 & Fo & E3 & $\begin{array}{l}\text { Currently 244-AR is isolated } \\
\text { from tank farms by removal of } \\
\text { jumper in } 241-A R-151 \\
\text { Requires very large quantity of } \\
\text { material to fill up } 244-A R \\
\text { facility (200K gallons } \\
\text { approximately) }\end{array}$ \\
\hline
\end{tabular}


Table B1. HAZOP Table - 244-AR Vault Facility

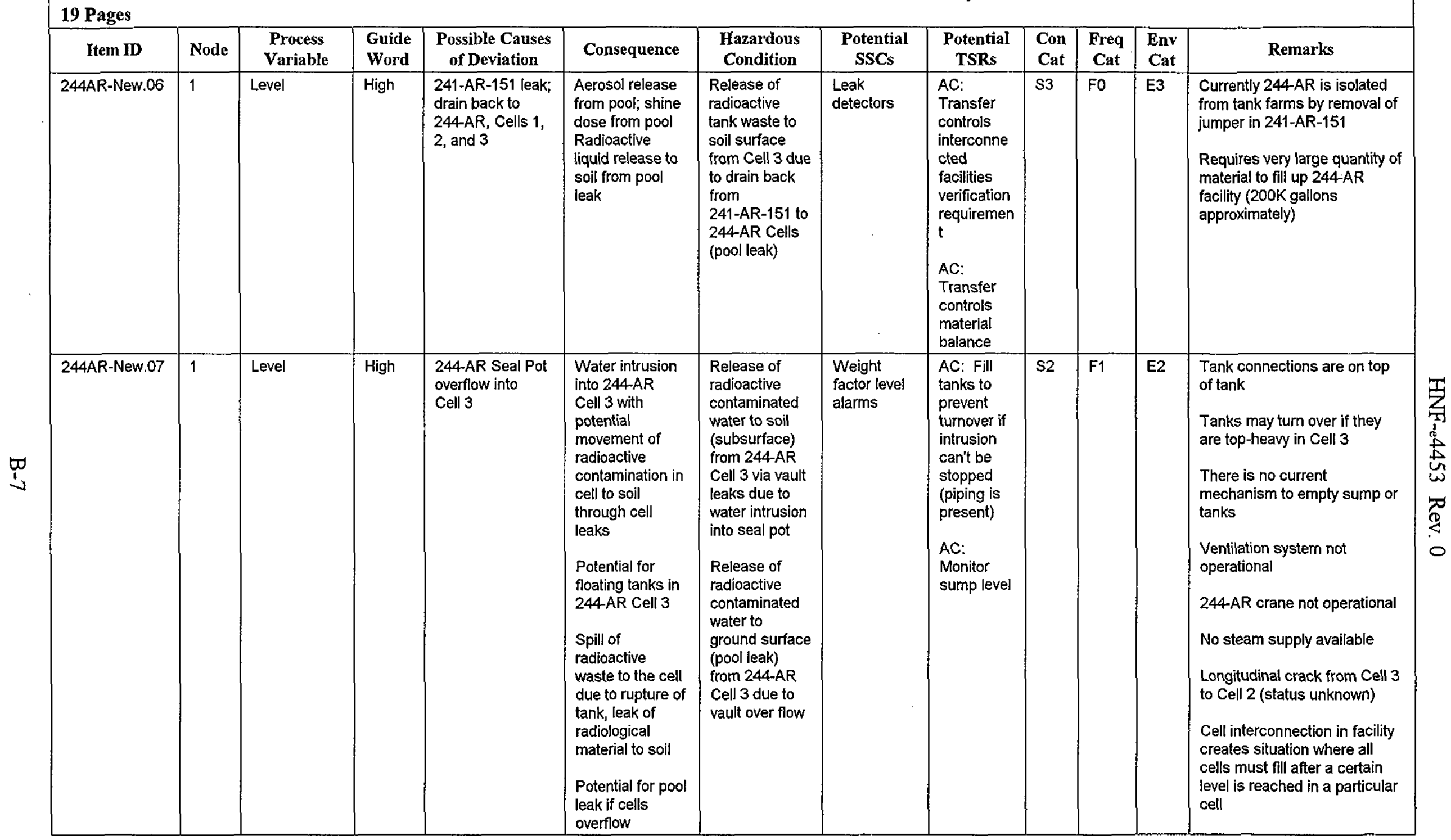


Table B1. HAZOP Table - 244-AR Vault Facility

\begin{tabular}{|c|c|c|c|c|c|c|c|c|c|c|c|c|}
\hline Item ID & Node & $\begin{array}{c}\text { Process } \\
\text { Variable }\end{array}$ & $\begin{array}{l}\text { Guide } \\
\text { Word }\end{array}$ & $\begin{array}{c}\text { Possible Causes } \\
\text { of Deviation }\end{array}$ & Consequence & $\begin{array}{l}\text { Hazardous } \\
\text { Condition }\end{array}$ & $\begin{array}{l}\text { Potential } \\
\text { SSCs }\end{array}$ & $\begin{array}{l}\text { Potential } \\
\text { TSRs }\end{array}$ & $\begin{array}{l}\text { Con } \\
\text { Cat }\end{array}$ & $\begin{array}{c}\text { Freq } \\
\text { Cat }\end{array}$ & $\begin{array}{l}\text { Env } \\
\text { Cat }\end{array}$ & Remarks \\
\hline 244AR-New.08 & 1 & Level & High & $\begin{array}{l}\text { General Intrusion: } \\
\text { Water line } \\
\text { ruptures Snow, } \\
\text { Rain }\end{array}$ & $\begin{array}{l}\text { Potential for } \\
\text { floating tanks in } \\
244-A R \text { Cell } 3 \text {, } \\
\text { Tank rupture of } \\
\text { TK-003 and } \\
\text { TK-004 with spill } \\
\text { of radiological } \\
\text { waste to cell, } \\
\text { leak of } \\
\text { radiological } \\
\text { material to soil }\end{array}$ & $\begin{array}{l}\text { Release of } \\
\text { radioactive } \\
\text { contaminated } \\
\text { water from } \\
\text { ruptured tank } \\
\text { TK-003 or } \\
\text { TK-004 to soil } \\
\text { (subsurface) } \\
\text { due to vault } \\
\text { leaks in } \\
\text { 244-AR Cell } 3\end{array}$ & $\begin{array}{l}\text { Service } \\
\text { water flow } \\
\text { totalizers } \\
\text { Weight } \\
\text { factor level } \\
\text { alarms }\end{array}$ & $\begin{array}{l}\text { AC: Fill } \\
\text { tanks to } \\
\text { prevent } \\
\text { turnover if } \\
\text { intrusion } \\
\text { can't be } \\
\text { stopped } \\
\text { (piping is } \\
\text { present) } \\
\text { AC: } \\
\text { Monitor } \\
\text { sump level } \\
\text { AC: } \\
\text { Service } \\
\text { water } \\
\text { monitoring }\end{array}$ & so & F1 & E2 & $\begin{array}{l}\text { No overflow from Cell } 3 \text { with } \\
\text { tanks TK-003 and TK-004 } \\
\text { resulting in float and rupture of } \\
\text { tanks in Cell } 3 \\
\text { Tank connections are on top } \\
\text { of tank } \\
\text { Tanks TK-003 and TK-004 } \\
\text { may turn over if Cell } 3 \text { fills with } \\
\text { water } \\
\text { There is no current } \\
\text { mechanism to empty sump or } \\
\text { tanks } \\
\text { Ventilation system not } \\
\text { operational } \\
244 \text { AR crane not operational } \\
\text { No steam supply available } \\
\text { Service water is isolated } \\
\text { Longitudinal crack from Cell } 3 \\
\text { to Cell } 2 \text { (status unknown) } \\
\text { Cell interconnection in facility } \\
\text { creates situation where all } \\
\text { cells must fill after a certain } \\
\text { level is reached in a particular } \\
\text { cell }\end{array}$ \\
\hline
\end{tabular}


Table B1. HAZOP Table - 244-AR Vault Facility

19 Pages

\begin{tabular}{|c|c|c|c|c|c|c|c|}
\hline Consequence & $\begin{array}{l}\text { Hazardous } \\
\text { Condition }\end{array}$ & $\begin{array}{c}\text { Potential } \\
\text { SSCs }\end{array}$ & $\begin{array}{l}\text { Potential } \\
\text { TSRs }\end{array}$ & $\begin{array}{l}\text { Con } \\
\text { Cat }\end{array}$ & $\begin{array}{c}\text { Freq } \\
\text { Cat }\end{array}$ & $\begin{array}{l}\text { Env } \\
\text { Cat }\end{array}$ & Remarks \\
\hline $\begin{array}{l}\text { Water intrusion } \\
\text { into } 244 \text {-AR } \\
\text { Cell } 3 \text { with } \\
\text { potential } \\
\text { movement of } \\
\text { radioactive } \\
\text { contamination in } \\
\text { cell to soil } \\
\text { through cell } \\
\text { leaks } \\
\text { Potential for } \\
\text { floating tanks in } \\
244-A R \text { Cell } 3 \\
\text { Spill of } \\
\text { radioactive } \\
\text { waste to the cell } \\
\text { due to rupture of } \\
\text { tank, leak of } \\
\text { radiological } \\
\text { material to soil } \\
\text { Potential for pool } \\
\text { leak if cells } \\
\text { overflow }\end{array}$ & $\begin{array}{l}\text { Release of } \\
\text { radioactive } \\
\text { contaminated } \\
\text { water to soil } \\
\text { (subsurface) } \\
\text { due to vault } \\
\text { leak from } \\
\text { 244-AR Cell } 3\end{array}$ & $\begin{array}{l}\text { Weight } \\
\text { factor level } \\
\text { alarms }\end{array}$ & $\begin{array}{l}\text { AC: Fill } \\
\text { tanks to } \\
\text { prevent } \\
\text { turnover if } \\
\text { intrusion } \\
\text { can't be } \\
\text { stopped } \\
\text { (piping is } \\
\text { present) } \\
\text { AC: } \\
\text { Monitor } \\
\text { sump level }\end{array}$ & so & $F 1$ & E2 & $\begin{array}{l}\text { No overflow from Cell } 3 \text { with } \\
\text { tanks TK-003 and TK-004 } \\
\text { resulting in float and rupture of } \\
\text { tanks in Cell } 3 \\
\text { Tank connections are on top } \\
\text { of tank } \\
\text { Tanks TK-003 and TK-004 } \\
\text { may turn over if Cell } 3 \text { fills with } \\
\text { water } \\
\text { There is no current } \\
\text { mechanism to empty sump or } \\
\text { tanks } \\
\text { Ventilation system not } \\
\text { operational } \\
244 \text { AR crane not operational } \\
\text { No steam supply available } \\
\text { Longitudinal crack from Cell } 3 \\
\text { to Cell } 2 \text { (status unknown) } \\
\text { Cell interconnection in facility } \\
\text { creates situation where all } \\
\text { cells must fill after a certain } \\
\text { level is reached in a particular } \\
\text { cell }\end{array}$ \\
\hline
\end{tabular}




\begin{tabular}{|c|c|c|c|c|c|c|c|c|c|c|c|c|}
\hline \multicolumn{13}{|c|}{ Table B1. HAZOP Table - 244-AR Vault Facility } \\
\hline Item ID & Node & $\begin{array}{c}\text { Process } \\
\text { Variable } \\
\end{array}$ & $\begin{array}{l}\text { Guide } \\
\text { Word }\end{array}$ & $\begin{array}{c}\text { Possible Causes } \\
\text { of Deviation }\end{array}$ & Consequence & $\begin{array}{l}\text { Hazardous } \\
\text { Condition }\end{array}$ & $\begin{array}{l}\text { Potential } \\
\text { SSCs }\end{array}$ & $\begin{array}{c}\text { Potential } \\
\text { TSRs }\end{array}$ & $\begin{array}{l}\text { Con } \\
\text { Cat }\end{array}$ & $\begin{array}{l}\text { Freq } \\
\text { Cat }\end{array}$ & $\begin{array}{l}\text { Env } \\
\text { Cat }\end{array}$ & Remarks \\
\hline 244AR-New.10 & 1 & Level & High & Seal Pot overflow & $\begin{array}{l}\text { Water intrusion } \\
\text { into } 244 \text { AR } \\
\text { Cell } 3 \text { with } \\
\text { potential } \\
\text { movement of } \\
\text { radioactive } \\
\text { contamination in } \\
\text { cell to soil } \\
\text { through cell } \\
\text { leaks } \\
\text { Potential for } \\
\text { floating tanks in } \\
244 \text { AR Cell } 3 \\
\text { Spill of } \\
\text { radioactive } \\
\text { waste to the cell } \\
\text { due to rupture of } \\
\text { tank, leak of } \\
\text { radiological } \\
\text { material to soil } \\
\text { (subsurface) }\end{array}$ & $\begin{array}{l}\text { Release of } \\
\text { radioactive } \\
\text { contaminated } \\
\text { water from } \\
\text { ruptured tank } \\
\text { TK-003 or } \\
\text { TK-004 to soil } \\
\text { (subsurface) } \\
\text { due to vault } \\
\text { leaks in } \\
\text { 244AR Cell } 3\end{array}$ & $\begin{array}{l}\text { Weight } \\
\text { factor level } \\
\text { alarms }\end{array}$ & $\begin{array}{l}\text { AC: Fill } \\
\text { tanks to } \\
\text { prevent } \\
\text { turnover if } \\
\text { intrusion } \\
\text { can't be } \\
\text { stopped } \\
\text { (piping is } \\
\text { present) } \\
\text { AC: } \\
\text { Monitor } \\
\text { sump level }\end{array}$ & so & F1 & E2 & $\begin{array}{l}\text { No overflow from Cell } 3 \text { with } \\
\text { tanks TK-003 and TK-004 } \\
\text { resulting in float and rupture of } \\
\text { tanks in Cell } 3 \\
\text { Tank connections are on top } \\
\text { of tank } \\
\text { Tanks TK-003 and TK-004 } \\
\text { may turn over if Cell } 3 \text { fills with } \\
\text { water } \\
\text { There is no current } \\
\text { mechanism to empty sump or } \\
\text { tanks } \\
\text { Ventilation system not } \\
\text { operational } \\
244-A R \text { crane not operational } \\
\text { No steam supply available } \\
\text { Longitudinal crack from Cell } 3 \\
\text { to Cell } 2 \text { (status unknown) } \\
\text { Cell interconnection in facility } \\
\text { creates situation where all } \\
\text { cells must fill after a certain } \\
\text { level is reached in a particular } \\
\text { cell }\end{array}$ \\
\hline \multicolumn{13}{|c|}{ Node 2 - Cell 2 including TK-002 } \\
\hline 244AR-New.11 & 2 & Temperature & Low & $\begin{array}{l}\text { Not considered a } \\
\text { problem - below } \\
\text { ground conditions } \\
\text { maintain constant } \\
\text { temperature - } \\
\text { there is no active } \\
\text { ventilation to } \\
\text { 244-AR Cell } 2\end{array}$ & None & None & None & None & N/A & $N / A$ & N/A & $\begin{array}{l}\text { Cell } 1 \text {, Cell } 3 \text { and Failed } \\
\text { Equipment Storage Tube } \\
\text { same as Cell } 2 \text { for this } \\
\text { condition }\end{array}$ \\
\hline 244AR-New.12 & 2 & Level & $\begin{array}{l}\text { Lowl } \\
\text { No }\end{array}$ & $\begin{array}{l}\text { Desired Condition } \\
\text { of } 244 \text { AR Cell } 2\end{array}$ & None & None & None & None & N/A & N/A & N/A & $\begin{array}{l}\text { Material dry out and } \\
\text { resuspension is not } \\
\text { considered a concern } \\
\text { because no active ventilation } \\
\text { in } 244 \text { AR Vault Facility }\end{array}$ \\
\hline
\end{tabular}




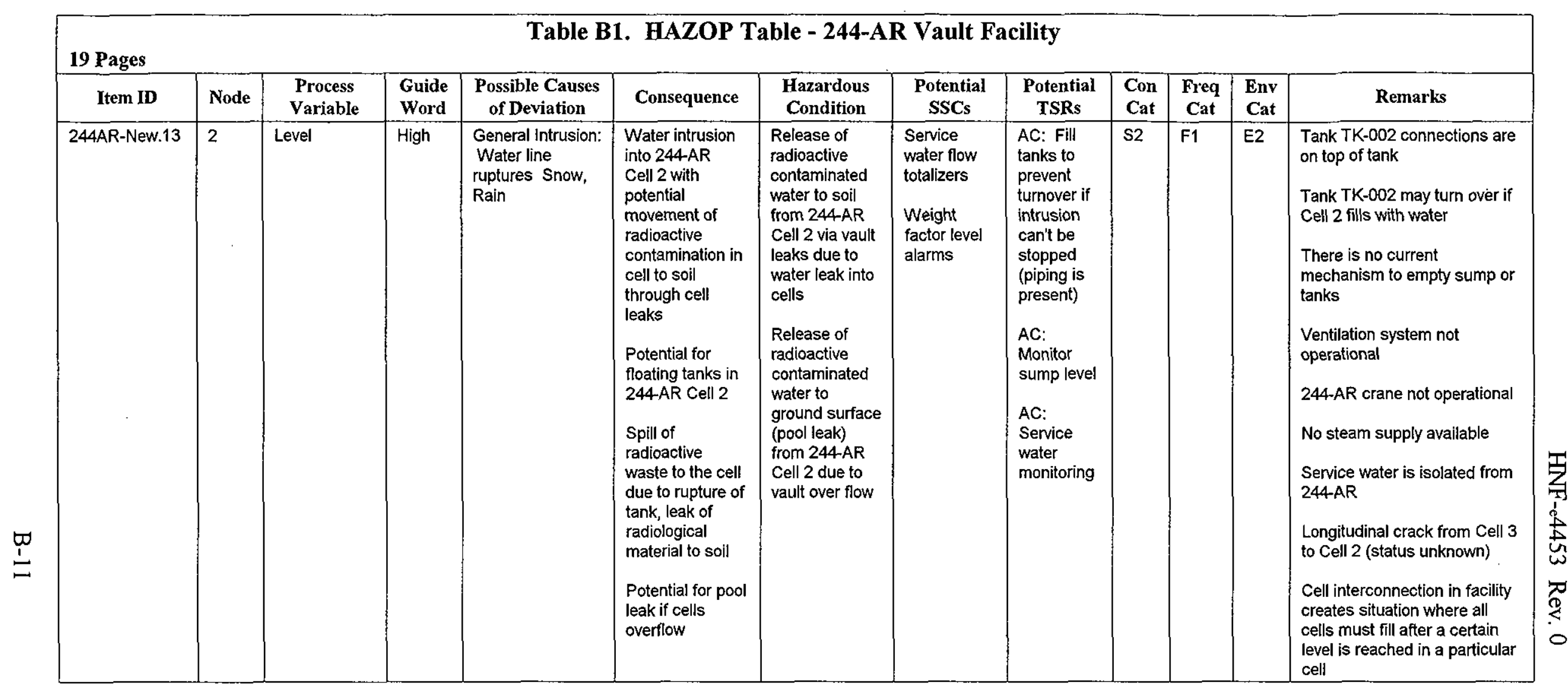




\begin{tabular}{|c|c|c|c|c|c|c|c|c|c|c|c|c|}
\hline \multicolumn{13}{|c|}{ Table B1. HAZOP Table - 244-AR Vault Facility } \\
\hline Item ID & Node & $\begin{array}{l}\text { Process } \\
\text { Variable }\end{array}$ & $\begin{array}{l}\text { Guide } \\
\text { Word }\end{array}$ & $\begin{array}{l}\text { Possible Causes } \\
\text { of Deviation }\end{array}$ & Consequence & $\begin{array}{l}\text { Hazardous } \\
\text { Condition }\end{array}$ & $\begin{array}{l}\text { Potential } \\
\text { SSCs }\end{array}$ & $\begin{array}{l}\text { Potential } \\
\text { TSRs }\end{array}$ & $\begin{array}{l}\text { Con } \\
\text { Cat }\end{array}$ & $\begin{array}{l}\text { Freq } \\
\text { Cat }\end{array}$ & $\begin{array}{l}\text { Env } \\
\text { Cat }\end{array}$ & Remarks \\
\hline 244AR-New.14 & 2 & Level & High & $\begin{array}{l}\text { Roof leaks over } \\
\text { 244AR Cell } 2\end{array}$ & $\begin{array}{l}\text { Water intrusion } \\
\text { into } 244 \text { AR } \\
\text { Cell } 2 \text { with } \\
\text { potential } \\
\text { movement of } \\
\text { radioactive } \\
\text { contamination in } \\
\text { cell to soil } \\
\text { through cell } \\
\text { leaks } \\
\text { Potential for } \\
\text { floating tank in } \\
244 \text { AR Cell } 2 \text {, } \\
\text { spill of } \\
\text { radioactive } \\
\text { waste to the cell } \\
\text { due to rupture of } \\
\text { tank, leak of } \\
\text { radiological } \\
\text { material to soil } \\
\text { Potential for pool } \\
\text { leak to } \\
\text { environment if } \\
\text { cells overflow }\end{array}$ & $\begin{array}{l}\text { Release of } \\
\text { radioactive } \\
\text { contaminated } \\
\text { water to soil } \\
\text { from } 244-A R \\
\text { Cell } 2 \text { via vault } \\
\text { leaks } \\
\text { Release of } \\
\text { radioactive } \\
\text { contaminated } \\
\text { water to } \\
\text { ground surface } \\
\text { (pool leak) } \\
\text { from 244-AR } \\
\text { Cell 2 due to } \\
\text { vault over flow }\end{array}$ & $\begin{array}{l}\text { Weight } \\
\text { factor level } \\
\text { alarms }\end{array}$ & $\begin{array}{l}\text { AC: Fill } \\
\text { tanks to } \\
\text { prevent } \\
\text { turnover if } \\
\text { intrusion } \\
\text { can't be } \\
\text { stopped } \\
\text { (piping is } \\
\text { present) } \\
\text { AC: } \\
\text { Monitor } \\
\text { sump level }\end{array}$ & s2 & F1 & E2 & $\begin{array}{l}\text { Tank TK-002 connections are } \\
\text { on top of tank } \\
\text { There is no current } \\
\text { mechanism to empty sump or } \\
\text { tanks } \\
\text { Ventilation system not } \\
\text { operational } \\
244-A R \text { crane not operational } \\
\text { No steam supply available } \\
\text { Longitudinal crack from Cell } 3 \\
\text { to Cell } 2 \text { (status unknown) } \\
\text { Cell interconnection in facility } \\
\text { creates situation where all } \\
\text { cells must fill after a certain } \\
\text { level is reached in a particular } \\
\text { cell }\end{array}$ \\
\hline 244AR-New.15 & 2 & Level & High & $\begin{array}{l}\text { Waste } \\
\text { mistransfers }\end{array}$ & $\begin{array}{l}\text { Aerosol release } \\
\text { from Pool leak } \\
\text { Radioactive } \\
\text { liquid release to } \\
\text { soil from Pool } \\
\text { leak }\end{array}$ & $\begin{array}{l}\text { Release of } \\
\text { radioactive } \\
\text { tank waste } \\
\text { from 244-AR } \\
\text { Cell } 2 \text { to soil } \\
\text { surface (pool } \\
\text { leak) due to a } \\
\text { waste } \\
\text { mistransfer } \\
\text { through } \\
\text { diversion box } \\
\text { 241-AR-151 }\end{array}$ & $\begin{array}{l}\text { Leak } \\
\text { detectors }\end{array}$ & $\begin{array}{l}\text { AC: } \\
\text { Transfer } \\
\text { controls } \\
\text { interconne } \\
\text { cted } \\
\text { facilities } \\
\text { verification } \\
\text { requiremen } \\
t \\
\text { AC: } \\
\text { Transfer } \\
\text { controls } \\
\text { material } \\
\text { balance }\end{array}$ & \$3 & Fo & E3 & $\begin{array}{l}\text { Currently } 244-A R \text { is isolated } \\
\text { from tank farms by removal of } \\
\text { jumper in } 244-A R-151 \\
\text { Requires very large quantity of } \\
\text { material to fill up } 244-A R \\
\text { facility (200K gallons } \\
\text { approximately) }\end{array}$ \\
\hline
\end{tabular}




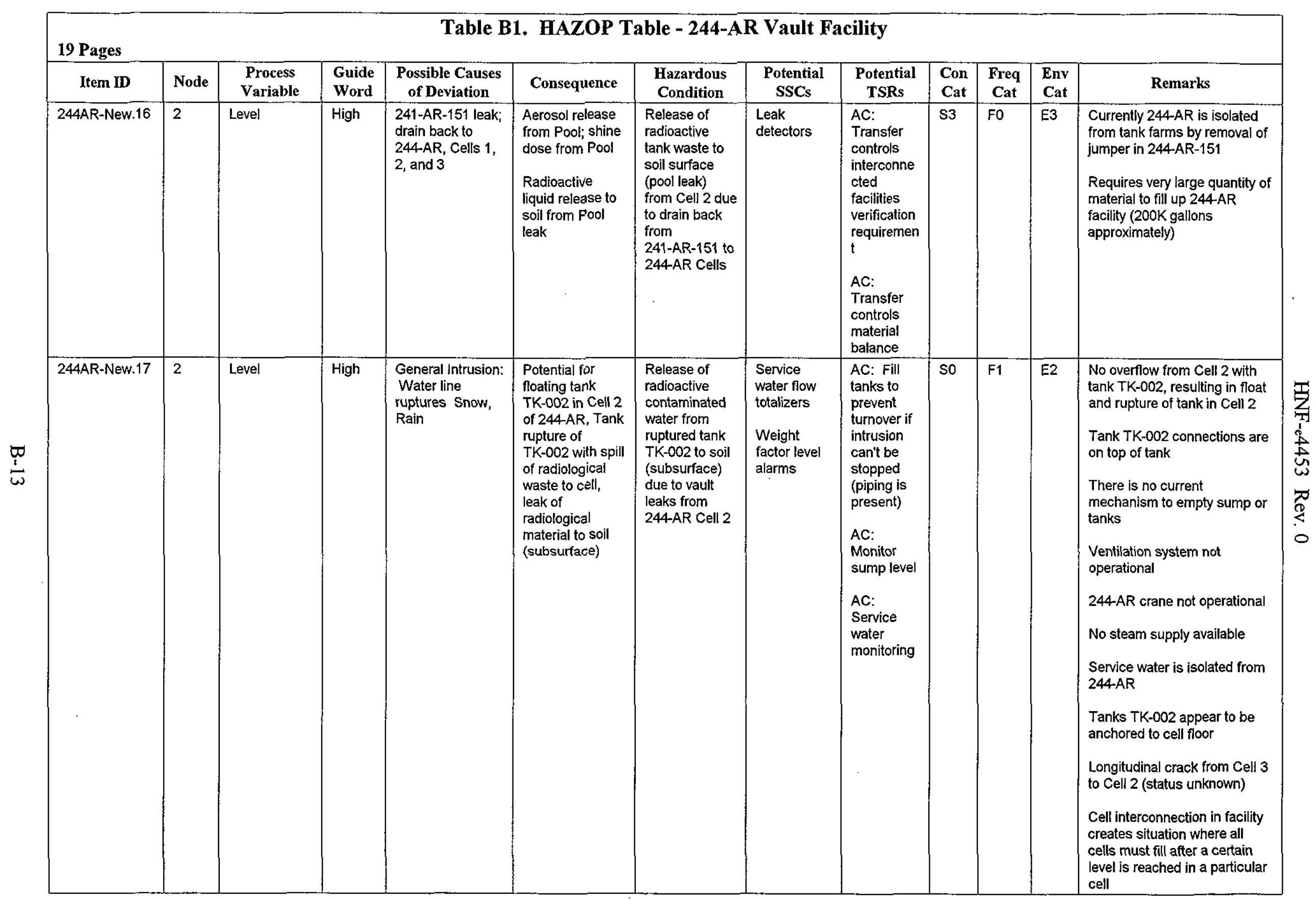




\begin{tabular}{|c|c|c|c|c|c|c|c|c|c|c|c|c|}
\hline \multicolumn{13}{|c|}{ Table B1. HAZOP Table - 244-AR Vault Facility } \\
\hline Item ID & Node & $\begin{array}{c}\text { Process } \\
\text { Variable }\end{array}$ & $\begin{array}{l}\text { Guide } \\
\text { Word }\end{array}$ & $\begin{array}{c}\text { Possible Causes } \\
\text { of Deviation }\end{array}$ & Consequence & $\begin{array}{c}\text { Hazardous } \\
\text { Condition }\end{array}$ & $\begin{array}{l}\text { Potential } \\
\text { SSCs }\end{array}$ & $\begin{array}{l}\text { Potential } \\
\text { TSRs }\end{array}$ & $\begin{array}{l}\text { Con } \\
\text { Cat }\end{array}$ & $\begin{array}{l}\text { Freq } \\
\text { Cat }\end{array}$ & $\begin{array}{l}\text { Env } \\
\text { Cat }\end{array}$ & Remarks \\
\hline 244AR-New.18 & 2 & Level & High & $\begin{array}{l}\text { Roof leaks over } \\
\text { 244-AR Cell } 2\end{array}$ & $\begin{array}{l}\text { Water intrusion } \\
\text { into } 244-A R \\
\text { Cell } 2 \text { with } \\
\text { potential } \\
\text { movement of } \\
\text { radioactive } \\
\text { contamination in } \\
\text { cell to soil } \\
\text { through cell } \\
\text { leaks } \\
\text { Potential for } \\
\text { floating tanks in } \\
244-A R \text { Cell } 2 \\
\text { Spill of } \\
\text { radioactive } \\
\text { waste to the cell } \\
\text { due to rupture of } \\
\text { tank, leak of } \\
\text { radiological } \\
\text { material to soil } \\
\text { (subsurface) }\end{array}$ & $\begin{array}{l}\text { Release of } \\
\text { radioactive } \\
\text { contaminated } \\
\text { water to soil } \\
\text { (subsurface) } \\
\text { due to vault } \\
\text { leak from } \\
\text { 244-AR Cell } 2\end{array}$ & $\begin{array}{l}\text { Weight } \\
\text { factor level } \\
\text { alarms }\end{array}$ & $\begin{array}{l}\text { AC: Fill } \\
\text { tanks to } \\
\text { prevent } \\
\text { turnover if } \\
\text { intrusion } \\
\text { can't be } \\
\text { stopped } \\
\text { (piping is } \\
\text { present) } \\
\text { AC: } \\
\text { Monitor } \\
\text { sump level }\end{array}$ & so & $\mathrm{F} 1$ & E2 & $\begin{array}{l}\text { No overflow from Cell } 2 \text { with } \\
\text { tank TK-002, resulting in float } \\
\text { and rupture of tank in Cell } 2 \\
\text { Tank TK-002 connections are } \\
\text { on top of tank } \\
\text { There is no current } \\
\text { mechanism to empty sump or } \\
\text { tanks } \\
\text { Ventilation system not } \\
\text { operational } \\
244-A R \text { crane not operational } \\
\text { No steam supply available } \\
\text { Longitudinal crack from Cell } 3 \\
\text { to Cell } 2 \text { (status unknown) } \\
\text { Cell interconnection in facility } \\
\text { creates situation where all } \\
\text { cells must fill after a certain } \\
\text { level is reached in a particular } \\
\text { cell }\end{array}$ \\
\hline
\end{tabular}


Table B1. HAZOP Table - 244-AR Vault Facility

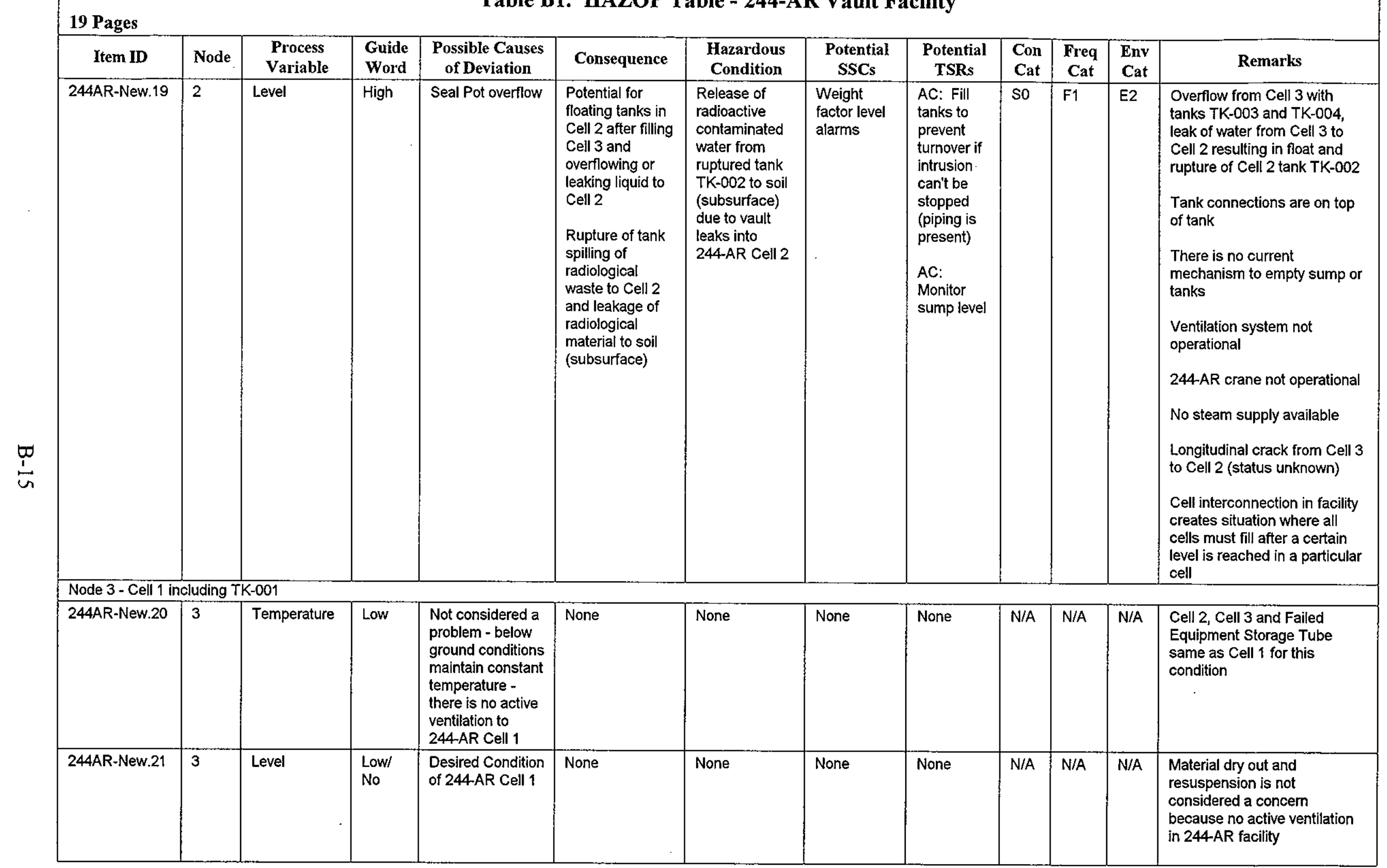




\begin{tabular}{|c|c|c|c|c|c|c|c|c|c|c|c|c|}
\hline \multicolumn{13}{|c|}{ Table B1. HAZOP Table - 244-AR Vault Facility } \\
\hline Item ID & Node & $\begin{array}{c}\text { Process } \\
\text { Variable }\end{array}$ & $\begin{array}{l}\text { Guide } \\
\text { Word }\end{array}$ & $\begin{array}{c}\text { Possible Causes } \\
\text { of Deviation }\end{array}$ & Consequence & $\begin{array}{c}\text { Hazardous } \\
\text { Condition }\end{array}$ & $\begin{array}{c}\text { Potential } \\
\text { SSCs }\end{array}$ & $\begin{array}{c}\text { Potential } \\
\text { TSRs } \\
\end{array}$ & $\begin{array}{l}\text { Con } \\
\text { Cat } \\
\end{array}$ & $\begin{array}{l}\text { Freq } \\
\text { Cat }\end{array}$ & $\begin{array}{l}\text { Env } \\
\text { Cat } \\
\end{array}$ & Remarks \\
\hline 244AR-New.22 & 3 & Level & High & $\begin{array}{l}\text { General Intrusion: } \\
\text { Water line } \\
\text { ruptures Snow, } \\
\text { Rain, Failed } \\
\text { equipment tube } \\
\text { leaks overlowing } \\
\text { into Cell } 1\end{array}$ & $\begin{array}{l}\text { Water intrusion } \\
\text { into } 244-A R \\
\text { Cell } 1 \text { with } \\
\text { potential } \\
\text { movement of } \\
\text { radioactive } \\
\text { contamination in } \\
\text { cell } \\
\text { Potential for } \\
\text { floating tank } \\
\text { TK-001 in Cell } 1 \\
\text { with rupture of } \\
\text { tank } \\
\text { Spill of } \\
\text { radiological } \\
\text { waste to cell, } \\
\text { leakage of } \\
\text { radiological } \\
\text { material to soil } \\
\text { Potential for pool } \\
\text { leak if } 244-A R \\
\text { vault cells } \\
\text { overflow }\end{array}$ & $\begin{array}{l}\text { Release of } \\
\text { radioactive } \\
\text { contaminated } \\
\text { water to soil } \\
\text { (subsurface) } \\
\text { from } 244-A R \\
\text { Cell } 1 \text { via vault } \\
\text { leaks due to } \\
\text { water leak into } \\
\text { cells } \\
\text { Release of } \\
\text { radioactive } \\
\text { contaminated } \\
\text { water to } \\
\text { ground surface } \\
\text { (Pool leak) } \\
\text { from } 244 \text {-AR } \\
\text { Cell } 1 \text { due to } \\
\text { vault over flow }\end{array}$ & $\begin{array}{l}\text { Service } \\
\text { water flow } \\
\text { totalizers } \\
\text { Weight } \\
\text { factor level } \\
\text { alarms }\end{array}$ & $\begin{array}{l}\text { AC: Fill } \\
\text { tanks to } \\
\text { prevent } \\
\text { turnover if } \\
\text { intrusion } \\
\text { can't be } \\
\text { stopped } \\
\text { (piping is } \\
\text { present) } \\
\text { AC: } \\
\text { Monitor } \\
\text { sump level } \\
\text { AC: } \\
\text { Service } \\
\text { water } \\
\text { monitoring }\end{array}$ & s2 & $\mathrm{F} 1$ & E2 & $\begin{array}{l}\text { Overflow from vault to soil } \\
\text { surface due to float and } \\
\text { rupture of tank TK-001 } \\
\text { Tank TK-001 connections are } \\
\text { on top of tank } \\
\text { Service water is isolated from } \\
244-A R \\
\text { There is no current } \\
\text { mechanism to empty sump or } \\
\text { tanks } \\
\text { Ventilation system not } \\
\text { operational } \\
\text { 244-AR crane not operational } \\
\text { No steam supply available for } \\
\text { jetting purposes } \\
\text { Interconnected condition of } \\
\text { cells will result in drainage } \\
\text { from cell to cell } \\
\text { Tank TK-001 appears to be } \\
\text { anchored to cell floor } \\
\text { Cell interconnection in facility } \\
\text { creates situation where all } \\
\text { cells must aill after a certain } \\
\text { level is reached in a particular } \\
\text { cell }\end{array}$ \\
\hline
\end{tabular}




\begin{tabular}{|c|c|c|c|c|c|c|c|c|c|c|c|c|}
\hline \multicolumn{13}{|c|}{ Table B1. HAZOP Table - 244-AR Vault Facility } \\
\hline Item ID & Node & $\begin{array}{l}\text { Process } \\
\text { Variable }\end{array}$ & $\begin{array}{l}\text { Guide } \\
\text { Word }\end{array}$ & $\begin{array}{c}\text { Possible Causes } \\
\text { of Deviation }\end{array}$ & Consequence & $\begin{array}{l}\text { Hazardous } \\
\text { Condition }\end{array}$ & $\begin{array}{l}\text { Potential } \\
\text { SSCs }\end{array}$ & $\begin{array}{c}\text { Potential } \\
\text { TSRs }\end{array}$ & $\begin{array}{l}\text { Con } \\
\text { Cat }\end{array}$ & $\begin{array}{c}\text { Freq } \\
\text { Cat }\end{array}$ & $\begin{array}{l}\text { Env } \\
\text { Cat }\end{array}$ & Remarks \\
\hline 244AR-New.23 & 3 & Level & High & $\begin{array}{l}\text { Roof leaks over } \\
\text { 244-AR Cell } 1\end{array}$ & $\begin{array}{l}\text { Water intrusion } \\
\text { into } 244 \text { AR } \\
\text { Cell } 1 \text { with } \\
\text { potential } \\
\text { movement of } \\
\text { radioactive } \\
\text { contamination in } \\
\text { cell } \\
\text { Potential for } \\
\text { floating tank } \\
\text { TK-001 in Cell } 1 \\
\text { with rupture of } \\
\text { tank } \\
\text { Spill of } \\
\text { radiological } \\
\text { waste to cell, } \\
\text { leakage of } \\
\text { radiological } \\
\text { material to soil } \\
\text { Potential pool } \\
\text { leak if facility } \\
\text { cells overflow }\end{array}$ & $\begin{array}{l}\text { Release of } \\
\text { radioactive } \\
\text { contaminated } \\
\text { water to soil } \\
\text { from } 244 \text { AR } \\
\text { Cell l via vault } \\
\text { leaks } \\
\text { Release of } \\
\text { radioactive } \\
\text { contaminated } \\
\text { water to } \\
\text { ground surface } \\
\text { (pool leak) } \\
\text { from } 244-A R \\
\text { Cell } 1 \text { due to } \\
\text { vault over flow }\end{array}$ & $\begin{array}{l}\text { Weight } \\
\text { factor level } \\
\text { alarms }\end{array}$ & $\begin{array}{l}\text { AC: Fill } \\
\text { tanks to } \\
\text { prevent } \\
\text { turnover if } \\
\text { intrusion } \\
\text { can't be } \\
\text { stopped } \\
\text { (piping is } \\
\text { present) } \\
\text { AC: } \\
\text { Monitor } \\
\text { sump level }\end{array}$ & S2 & F1 & E2 & $\begin{array}{l}\text { Tank TK-001 connections are } \\
\text { on top of tank } \\
\text { There is no current } \\
\text { mechanism to empty sump or } \\
\text { tanks } \\
\text { Ventilation system not } \\
\text { operational } \\
\text { 244-AR crane not operational } \\
\text { No steam supply available for } \\
\text { jetting purposes } \\
\text { Interconnected condition of } \\
\text { cells will result in drainage } \\
\text { from cell to cell } \\
\text { Tank TK-o01 appears to be } \\
\text { anchored to cell floor } \\
\text { Cell interconnection in facility } \\
\text { creates situation where all } \\
\text { cells must fill after a certain } \\
\text { level is reached in a particular } \\
\text { cell }\end{array}$ \\
\hline 244AR-New.24 & 3 & Level & High & $\begin{array}{l}\text { Waste } \\
\text { mistransfers }\end{array}$ & $\begin{array}{l}\text { Aerosol release } \\
\text { from pool leak } \\
\text { Radioactive } \\
\text { liquid release to } \\
\text { soil from pool } \\
\text { leak }\end{array}$ & $\begin{array}{l}\text { Release of } \\
\text { radioactive } \\
\text { tank waste } \\
\text { from } 244-A R \\
\text { Cell } 1 \text { to soil } \\
\text { surface (pool } \\
\text { leak) due to a } \\
\text { waste } \\
\text { mistransfer } \\
\text { through } \\
\text { diversion box } \\
241-A R-151\end{array}$ & $\begin{array}{l}\text { Leak } \\
\text { detectors }\end{array}$ & $\begin{array}{l}\text { AC: } \\
\text { Transfer } \\
\text { controls } \\
\text { interconne } \\
\text { cted } \\
\text { facilities } \\
\text { verification } \\
\text { requiremen } \\
\text { t AC: } \\
\text { Transfer } \\
\text { controls } \\
\text { material } \\
\text { balance }\end{array}$ & s3 & Fo & E3 & $\begin{array}{l}\text { Currently } 244-A R \text { is isolated } \\
\text { from tank farms by removal of } \\
\text { jumper in } 244-A R-151 \\
\text { Requires very large quantity of } \\
\text { material to fill up } 244-A R \\
\text { facility (200K gallons } \\
\text { approximately) }\end{array}$ \\
\hline
\end{tabular}


Table B1. HAZOP Table - 244-AR Vault Facility

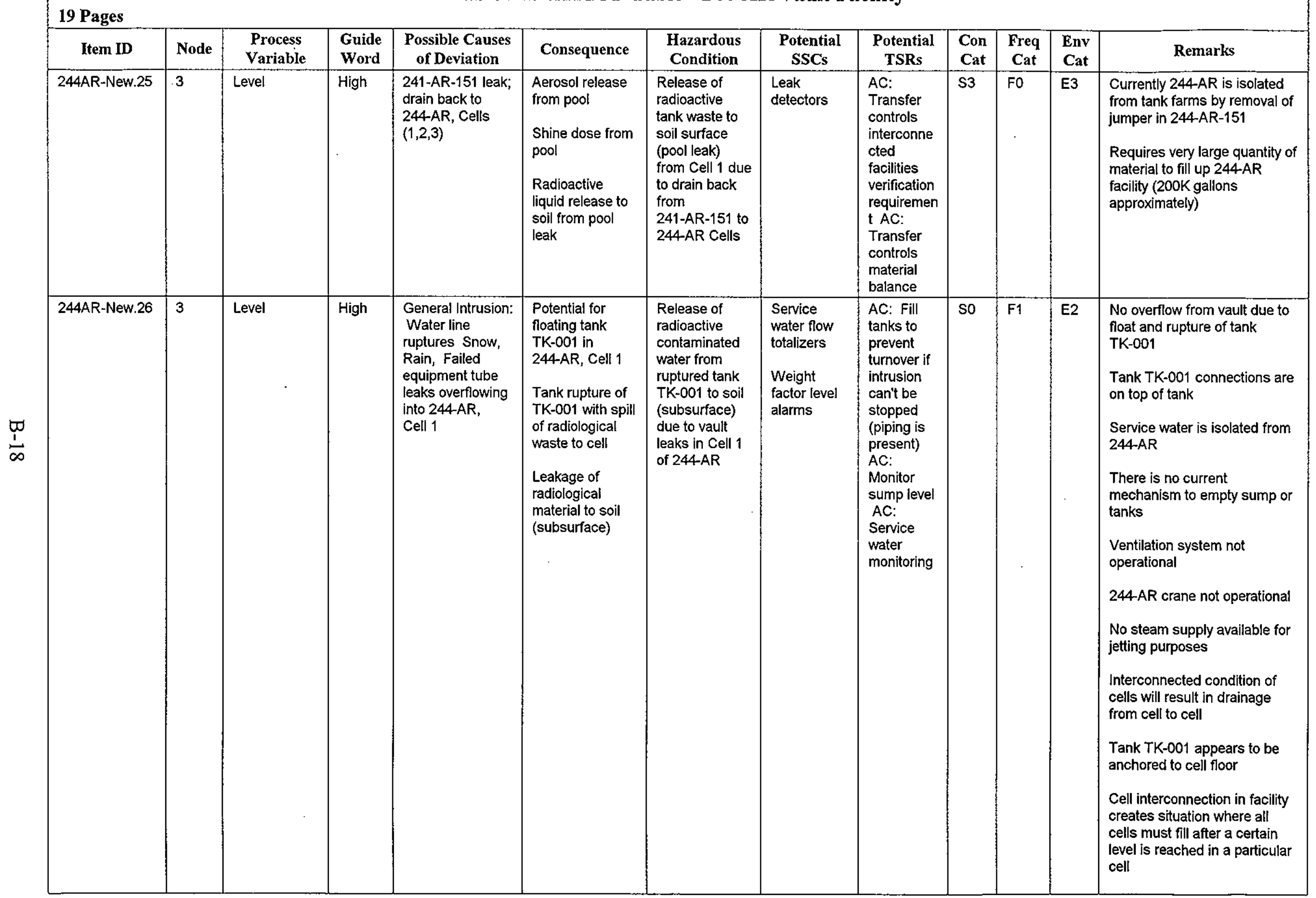


Table B1. HAZOP Table - 244-AR Vault Facility

\begin{tabular}{|c|c|c|c|c|c|c|c|c|c|c|c|c|}
\hline Item ID & Node & $\begin{array}{c}\text { Process } \\
\text { Variable }\end{array}$ & $\begin{array}{l}\text { Guide } \\
\text { Word }\end{array}$ & $\begin{array}{c}\text { Possible Causes } \\
\text { of Deviation }\end{array}$ & Consequence & $\begin{array}{l}\text { Hazardous } \\
\text { Condition }\end{array}$ & $\begin{array}{c}\text { Potential } \\
\text { SSCs }\end{array}$ & $\begin{array}{l}\text { Potential } \\
\text { TSRs }\end{array}$ & $\begin{array}{l}\text { Con } \\
\text { Cat }\end{array}$ & $\begin{array}{l}\text { Freq } \\
\text { Cat }\end{array}$ & $\begin{array}{l}\text { Env } \\
\text { Cat }\end{array}$ & Remarks \\
\hline 244AR-New.27 & 3 & Level & High & $\begin{array}{l}\text { Roof leaks over } \\
\text { 244-AR Cell } 1\end{array}$ & $\begin{array}{l}\text { Water intrusion } \\
\text { into } 244-A R \\
\text { Cell } 1 \text { with } \\
\text { potential } \\
\text { movement of } \\
\text { radioactive } \\
\text { contamination in } \\
\text { cell to soil } \\
\text { through cell } \\
\text { leaks } \\
\text { Potential for } \\
\text { floating tank } \\
\text { TK-001 in } \\
244 \text { AR Cell } 1 \\
\text { with spill of } \\
\text { radioactive } \\
\text { waste to the cell } \\
\text { due to rupture of } \\
\text { tank } \\
\text { Leakage of } \\
\text { radiological } \\
\text { material to soil } \\
\text { Potential pool } \\
\text { leak to } \\
\text { environment if } \\
244 \text { AR vault } \\
\text { cells overflow }\end{array}$ & $\begin{array}{l}\text { Release of } \\
\text { radioactive } \\
\text { contaminated } \\
\text { water to soil } \\
\text { (subsurface) } \\
\text { due to vault } \\
\text { leak from } \\
\text { 244-AR, Cell } 1\end{array}$ & $\begin{array}{l}\text { Weight } \\
\text { factor level } \\
\text { alarms }\end{array}$ & $\begin{array}{l}\text { AC: Fill } \\
\text { tanks to } \\
\text { prevent } \\
\text { turnover if } \\
\text { intrusion } \\
\text { can't be } \\
\text { stopped } \\
\text { (piping is } \\
\text { present) } \\
\text { AC: } \\
\text { Monitor } \\
\text { sump level } \\
\text { AC: } \\
\text { Service } \\
\text { water } \\
\text { monitoring }\end{array}$ & so & $F 1$ & $\overline{E 2}$ & $\begin{array}{l}\text { No overflow from vault due to } \\
\text { float and rupture of tank } \\
\text { TK-001 } \\
\text { Tank TK-001 connections are } \\
\text { on top of tank } \\
\text { There is no current } \\
\text { mechanism to empty sump or } \\
\text { tanks } \\
\text { Ventilation system not } \\
\text { operational } \\
\text { 244-AR crane not operational } \\
\text { No steam supply available for } \\
\text { jetting purposes } \\
\text { Interconnected condition of } \\
\text { cells will result in drainage } \\
\text { from cell to cell } \\
\text { Tank TK-001 appears to be } \\
\text { anchored to cell floor } \\
\text { Cell interconnection in facility } \\
\text { creates situation where all } \\
\text { cells must fill after a certain } \\
\text { level is reached in a particular } \\
\text { cell }\end{array}$ \\
\hline \multicolumn{13}{|c|}{ Node 4 - Failed Equipment Storage Tubes } \\
\hline 244AR-New.28 & 4 & Temperature & Low & $\begin{array}{l}\text { Not considered a } \\
\text { problem - below } \\
\text { ground conditions } \\
\text { maintain constant } \\
\text { temperature - } \\
\text { there is no active } \\
\text { ventilation to } \\
\text { 244-AR Failed } \\
\text { Equipment } \\
\text { Storage Tube }\end{array}$ & None & None & None & None & N/A & $\mathrm{N} / \mathrm{A}$ & $\mathrm{N} / \mathrm{A}$ & $\begin{array}{l}\text { Failed Equipment Storage } \\
\text { Tube same as } 244-A R \text {, Cells } \\
1,2 \text {, and } 3 \text { for this condition }\end{array}$ \\
\hline
\end{tabular}




\begin{tabular}{|c|c|c|c|c|c|c|c|c|c|c|c|c|}
\hline \multicolumn{13}{|c|}{ Table B1. HAZOP Table - 244-AR Vault Facility } \\
\hline Item ID & Node & $\begin{array}{c}\text { Process } \\
\text { Variable } \\
\end{array}$ & $\begin{array}{l}\text { Guide } \\
\text { Word }\end{array}$ & $\begin{array}{c}\text { Possible Causes } \\
\text { of Deviation }\end{array}$ & Consequence & $\begin{array}{c}\text { Hazardous } \\
\text { Condition }\end{array}$ & $\begin{array}{c}\text { Potential } \\
\text { SSCs }\end{array}$ & $\begin{array}{c}\text { Potential } \\
\text { TSRs }\end{array}$ & $\begin{array}{l}\text { Con } \\
\text { Cat }\end{array}$ & $\begin{array}{c}\text { Freq } \\
\text { Cat }\end{array}$ & $\begin{array}{l}\text { Env } \\
\text { Cat }\end{array}$ & Remarks \\
\hline 244AR-New.29 & 4 & Level & $\begin{array}{l}\text { Low/ } \\
\text { No }\end{array}$ & $\begin{array}{l}\text { Desired Condition } \\
\text { of } 244-A R \text { Failed } \\
\text { Equipment } \\
\text { Storage Tube }\end{array}$ & None & None & None & None & N/A & N/A & N/A & $\begin{array}{l}\text { Material dry out and } \\
\text { resuspension is not } \\
\text { considered a concern } \\
\text { because there is no active } \\
\text { ventilation in 244-AR facility } \\
\text { For Failed Equipment Storage } \\
\text { Facility no liquid in the cell is } \\
\text { the desired condition }\end{array}$ \\
\hline 244AR-New.30 & 4 & Level & High & $\begin{array}{l}\text { Roof leak over } \\
\text { Failed Equipment } \\
\text { Storage Tube }\end{array}$ & $\begin{array}{l}\text { Flooding of the } \\
\text { 244AR Failed } \\
\text { Equipment } \\
\text { Storage Tube } \\
\text { and leak of } \\
\text { radiological } \\
\text { material to soil } \\
\text { (subsurface) }\end{array}$ & $\begin{array}{l}\text { Release of } \\
\text { radioactive } \\
\text { contaminated } \\
\text { water to soil } \\
\text { (subsurface) } \\
\text { from 244-AR } \\
\text { Failed } \\
\text { Equipment } \\
\text { Tube due to } \\
\text { roof leak and } \\
\text { leakage from } \\
\text { tube }\end{array}$ & $\begin{array}{l}\text { Weight } \\
\text { factor level } \\
\text { alarms }\end{array}$ & $\begin{array}{l}\text { AC: } \\
\text { Monitor } \\
\text { sump level } \\
\text { in Cell } 1\end{array}$ & so & F1 & E2 & $\begin{array}{l}\text { Any inflow into Failed } \\
\text { Equipment Storage Tube } \\
\text { results inflow into Cell } 1 \text { due to } \\
\text { interconnecting drain pipe at } \\
\text { bottom of cell and tube } \\
\text { Cell interconnection in facility } \\
\text { creates situation where all } \\
\text { cells must fill after à certain } \\
\text { level is reached in a particular } \\
\text { cell }\end{array}$ \\
\hline 244AR-New.31 & 4 & Level & High & $\begin{array}{l}\text { General Intrusion: } \\
\text { Water line } \\
\text { ruptures, Snow, } \\
\text { Rain }\end{array}$ & $\begin{array}{l}\text { Flooding of the } \\
\text { 244AR Failed } \\
\text { Equipment } \\
\text { Storage Tube } \\
\text { and leak of } \\
\text { radiological } \\
\text { material to soil. } \\
\text { (subsurface) }\end{array}$ & $\begin{array}{l}\text { Release of } \\
\text { radioactive } \\
\text { contaminated } \\
\text { water to soil } \\
\text { (subsurface) } \\
\text { from } 244-A R \\
\text { Failed } \\
\text { Equipment } \\
\text { Tube due to } \\
\text { roof leak and } \\
\text { leakage from } \\
\text { tube }\end{array}$ & $\begin{array}{l}\text { Weight } \\
\text { factor level } \\
\text { alarms }\end{array}$ & $\begin{array}{l}\text { AC: } \\
\text { Monitor } \\
\text { sump level } \\
\text { in Cell } 1\end{array}$ & so & F1 & E2 & $\begin{array}{l}\text { Any inflow into Failed } \\
\text { Equipment Storage Tube } \\
\text { results inflow into Cell } 1 \text { due to } \\
\text { interconnecting drain pipe at } \\
\text { bottom of cell and tube } \\
\text { Cell interconnection in facility } \\
\text { creates situation where all } \\
\text { cells must fill after a certain } \\
\text { level is reached in a particular } \\
\text { cell }\end{array}$ \\
\hline \multicolumn{13}{|c|}{ Node 5 - Seal Pot Pit } \\
\hline 244AR-New.32 & 5 & Temperature & Low & $\begin{array}{l}\text { Not considered a } \\
\text { problem - below } \\
\text { ground conditions } \\
\text { maintain constant } \\
\text { temperature - } \\
\text { there is no active } \\
\text { ventilation to } \\
\text { 244-AR Seal Pot } \\
\text { Pit } \\
\end{array}$ & None & None & None & None & so & $\mathrm{F1}$ & E2 & $\begin{array}{l}\text { Seal Pot same as } 244-A R \\
\text { Cells } 1,2, \text { and } 3 \text {, and the } \\
\text { Failed Equipment Storage } \\
\text { Tube for this condition } \\
\text { If Seal Pot freezes and break } \\
\text { occurs, there would be a spill } \\
\text { to the soil (subsurface) }\end{array}$ \\
\hline
\end{tabular}




\begin{tabular}{|c|c|c|c|c|c|c|c|c|c|c|c|c|}
\hline \multicolumn{13}{|c|}{ Table B1. HAZOP Table - 244-AR Vault Facility } \\
\hline Item ID & Node & $\begin{array}{c}\text { Process } \\
\text { Variable }\end{array}$ & $\begin{array}{l}\text { Guide } \\
\text { Word }\end{array}$ & $\begin{array}{c}\text { Possible Causes } \\
\text { of Deviation }\end{array}$ & Consequence & $\begin{array}{c}\text { Hazardous } \\
\text { Condition }\end{array}$ & $\begin{array}{l}\text { Potential } \\
\text { SSCs }\end{array}$ & $\begin{array}{c}\text { Potential } \\
\text { TSRs }\end{array}$ & $\begin{array}{l}\text { Con } \\
\text { Cat }\end{array}$ & $\begin{array}{l}\text { Freq } \\
\text { Cat }\end{array}$ & $\begin{array}{l}\text { Env } \\
\text { Cat }\end{array}$ & Remarks \\
\hline 244AR-New.33 & 5 & Level & $\begin{array}{l}\text { Low/ } \\
\text { No }\end{array}$ & $\begin{array}{l}\text { Desired Condition } \\
\text { of } 244-A R \text { Seal } \\
\text { Pot }\end{array}$ & None & None & None & None & N/A & N/A & N/A & $\begin{array}{l}\text { Material dry out and } \\
\text { resuspension is not } \\
\text { considered a concern } \\
\text { because there is no active } \\
\text { ventilation in 244-AR Vault } \\
\text { Facility } \\
\text { For seal pot low level is the } \\
\text { desired condition, no level is } \\
\text { undesirable but not a } \\
\text { significant threat }\end{array}$ \\
\hline 244AR-New.34 & 5 & Level & High & $\begin{array}{l}\text { General Intrusion: } \\
\text { Vessel vent } \\
\text { prefilter drain, } \\
\text { Main vessel vent } \\
\text { filter vault, } \\
\text { Vessel Vent } \\
\text { Stack }\end{array}$ & $\begin{array}{l}\text { Potential for } \\
\text { floating Seal Pot } \\
\text { in Seal Pot Pit } \\
\text { resulting in } \\
\text { rupture of Seal } \\
\text { Pot } \\
\text { Spill of } \\
\text { radiological } \\
\text { waste to Pit, leak } \\
\text { of radiological } \\
\text { material to soil } \\
\text { (subsurface) }\end{array}$ & $\begin{array}{l}\text { Release of } \\
\text { radioactive } \\
\text { contaminated } \\
\text { water to soil } \\
\text { (subsurface) } \\
\text { from 244-AR } \\
\text { Seal Pot Pit } \\
\text { due to in } \\
\text { leakage of } \\
\text { liquid into pit } \\
\text { resulting in } \\
\text { rupture of pot }\end{array}$ & None & None & so & $\mathrm{F} 1$ & E2 & $\begin{array}{l}\text { Cell interconnection in facility } \\
\text { creates situation where all } \\
\text { cells must fill after a certain } \\
\text { level is reached in a particular } \\
\text { level }\end{array}$ \\
\hline
\end{tabular}

Abbreviations:

AC - Administrative Control

BIO - Basis for Interim Operation

DF - Design Feature

LCO - Limiting Condition for Operation 
HNF-e4453 Rev. 0

This page intentionally left blank 
HNF-4453 Rev. 0

\begin{tabular}{|c|c|c|c|c|}
\hline \multicolumn{5}{|c|}{$\begin{array}{l}\text { Table B2. Hazardous Conditions With Potential Significant Offsite Consequences (S3) } \\
\text { 1 Page }\end{array}$} \\
\hline ID & Cause & Hazardous Condition & $\begin{array}{l}\text { Freq } \\
\text { Cat }\end{array}$ & $\begin{array}{l}\text { Env } \\
\text { Cat }\end{array}$ \\
\hline 244AR-New.05 & Waste mistransfers & $\begin{array}{l}\text { Release of radioactive tank waste from } 244-\mathrm{AR} \\
\text { Cell } 3 \text { to soil surface (pool leak) due to a waste } \\
\text { mistransfer through diversion box } 241 \text {-AR-151 }\end{array}$ & F0 & E3 \\
\hline 244AR-New.06 & $\begin{array}{l}\text { 241-AR-151 leak; drain back to } \\
244-A R \text {, Cells } 1,2 \text {, and } 3\end{array}$ & $\begin{array}{l}\text { Release of radioactive tank waste to soil surface from } \\
\text { Cell } 3 \text { due to drain back from } 241-A R-151 \text { to } \\
\text { 244-AR Cells (pool leak) }\end{array}$ & F0 & E3 \\
\hline 244AR-New.15 & Waste mistransfers & $\begin{array}{l}\text { Release of radioactive tank waste from } 244-\mathrm{AR} \\
\text { Cell } 2 \text { to soil surface (pool leak) due to a waste } \\
\text { mistransfer through diversion box } 241 \text {-AR-151 }\end{array}$ & FO & E3 \\
\hline 244AR-New.16 & $\begin{array}{l}\text { 241-AR-151 leak; drain back to } \\
\text { 244-AR, Cells } 1,2 \text {, and } 3\end{array}$ & $\begin{array}{l}\text { Release of radioactive tank waste to soil surface (pool } \\
\text { leak) from Cell } 2 \text { due to drain back from } \\
241-A R-151 \text { to } 244-A R \text { Cells }\end{array}$ & F0 & E3 \\
\hline 244AR-New.24 & Waste mistransfers & $\begin{array}{l}\text { Release of radioactive tank waste from } 244-\mathrm{AR} \\
\text { Cell } 1 \text { to soil surface (pool leak) due to a waste } \\
\text { mistransfer through diversion box } 241-\mathrm{AR}-151\end{array}$ & F0 & E3 \\
\hline 244AR-New.25 & $\begin{array}{l}\text { 241-AR-151 leak; drain back to } \\
244-A R \text {, Cells }(1,2,3)\end{array}$ & $\begin{array}{l}\text { Release of radioactive tank waste to soil surface (pool } \\
\text { leak) from Cell } 1 \text { due to drain back from } \\
241-A R-151 \text { to } 244-A R \text { Cells }\end{array}$ & F0 & $\mathrm{E} 3$ \\
\hline
\end{tabular}


HNF-4453 Rev. 0

This page intentionally left blank 
HNF-4453 Rev. 0

\begin{tabular}{|c|c|c|c|c|}
\hline \multicolumn{5}{|c|}{$\begin{array}{l}\text { Table B3. Hazardous Conditions With Potential Significant Onsite Consequences (S2) } \\
\text { 2 Pages }\end{array}$} \\
\hline ID & Cause & Hazardous Condition & $\begin{array}{l}\text { Freq } \\
\text { Cat }\end{array}$ & $\begin{array}{l}\text { Env } \\
\text { Cat }\end{array}$ \\
\hline 244AR-New.03 & $\begin{array}{l}\text { General Intrusion: Water line } \\
\text { ruptures Snow, Rain }\end{array}$ & $\begin{array}{l}\text { Release of radioactive contaminated water to soil } \\
\text { (subsurface) from } 244 \text {-AR Cell } 3 \text { via vault leaks due } \\
\text { to water leak into cells } \\
\text { Release of radioactive contaminated water to ground } \\
\text { surface (pool leak) from } 244 \text {-AR Cell } 3 \text { due to vault } \\
\text { over flow }\end{array}$ & $\mathrm{F} 1$ & $\mathrm{E} 2$ \\
\hline 244AR-New.04 & Roof leaks over 244-AR Cell 3 & $\begin{array}{l}\text { Release of radioactive contaminated water to soil } \\
\text { (subsurface) from } 244 \text {-AR Cell } 3 \text { via vault leaks } \\
\text { Release of radioactive contaminated water to ground } \\
\text { surface (pool leak) 244-AR Cell } 3 \text { due to vault over } \\
\text { flow }\end{array}$ & $\mathrm{F} 1$ & $\mathrm{E} 2$ \\
\hline 244AR-New.07 & $\begin{array}{l}\text { 244-AR Seal Pot overflow into } \\
\text { Cell } 3\end{array}$ & $\begin{array}{l}\text { Release of radioactive contaminated water to soil } \\
\text { (subsurface) from } 244-A R \text { Cell } 3 \text { via vault leaks due } \\
\text { to water intrusion into seal pot } \\
\text { Release of radioactive contaminated water to ground } \\
\text { surface (pool leak) from } 244 \text {-AR Cell } 3 \text { due to vault } \\
\text { over flow }\end{array}$ & $\mathrm{F} 1$ & E2 \\
\hline 244AR-New.13 & $\begin{array}{l}\text { General Intrusion: Water line } \\
\text { ruptures Snow, Rain }\end{array}$ & $\begin{array}{l}\text { Release of radioactive contaminated water to soil from } \\
244-A R \text { Cell } 2 \text { via vault leaks due to water leak into } \\
\text { cells } \\
\text { Release of radioactive contaminated water to ground } \\
\text { surface (pool leak) from } 244-A R \text { Cell } 2 \text { due to vault } \\
\text { over flow }\end{array}$ & $\mathrm{Fl}$ & $\mathrm{E} 2$ \\
\hline 244AR-New.14 & Roof leaks over $244-A R$ Cell 2 & $\begin{array}{l}\text { Release of radioactive contaminated water to soil from } \\
\text { 244-AR Cell } 2 \text { via vault leaks } \\
\text { Release of radioactive contaminated water to ground } \\
\text { surface (pool leak) from } 244-A R \text { Cell } 2 \text { due to vault } \\
\text { over flow }\end{array}$ & F1 & $\mathrm{E} 2$ \\
\hline 244AR-New. 22 & $\begin{array}{l}\text { General Intrusion: Water line } \\
\text { ruptures Snow, Rain, Failed } \\
\text { equipment tube leaks overflowing } \\
\text { into Cell l }\end{array}$ & $\begin{array}{l}\text { Release of radioactive contaminated water to soil } \\
\text { (subsurface) from } 244 \text {-AR Cell } 1 \text { via vault leaks due } \\
\text { to water leak into cells } \\
\text { Release of radioactive contaminated water to ground } \\
\text { surface (Pool leak) from } 244-A R \text { Cell } 1 \text { due to vault } \\
\text { over flow }\end{array}$ & F1 & $\mathrm{E} 2$ \\
\hline
\end{tabular}


HNF-4453 Rev. 0

\begin{tabular}{|c|c|c|c|c|}
\hline $\begin{array}{l}\text { Table I } \\
2 \text { Pages }\end{array}$ & Hazardous Condition & h Potential Significant Onsite Conseque & $(\mathrm{S}$ & \\
\hline ID & Cause & Hazardous Condition & $\begin{array}{l}\text { Freq } \\
\text { Cat }\end{array}$ & $\begin{array}{l}\text { Env } \\
\text { Cat }\end{array}$ \\
\hline 244AR-New.23 & Roof leaks over 244-AR Cell 1 & $\begin{array}{l}\text { Release of radioactive contaminated water to soil from } \\
244 \text {-AR Cell } 1 \text { via vault leaks } \\
\text { Release of radioactive contaminated water to ground } \\
\text { surface (pool leak) from } 244 \text {-AR Cell } 1 \text { due to vault } \\
\text { over flow }\end{array}$ & F1 & $\mathrm{E} 2$ \\
\hline
\end{tabular}


HNF-4453 Rev. 0

\begin{tabular}{|c|c|c|c|c|}
\hline \multicolumn{5}{|c|}{ Table B4. Hazardous Conditions With No Significant Consequences (S0) } \\
\hline ID & Cause & Hazardous Condition & $\begin{array}{l}\text { Freq } \\
\text { Cat }\end{array}$ & $\begin{array}{l}\text { Env } \\
\text { Cat }\end{array}$ \\
\hline 244AR-New.08 & $\begin{array}{l}\text { General Intrusion: Water line } \\
\text { ruptures Snow, Rain }\end{array}$ & $\begin{array}{l}\text { Release of radioactive contaminated water from } \\
\text { ruptured tank TK-003 or TK-004 to soil } \\
\text { (subsurface) due to vault leaks in 244-AR Cell } 3\end{array}$ & $\mathrm{~F} 1$ & $\mathrm{E} 2$ \\
\hline 244AR-New.09 & Roof leaks over 244-AR Cell 3 & $\begin{array}{l}\text { Release of radioactive contaminated water to soil } \\
\text { (subsurface) due to vault leak from } 244 \text {-AR Cell } 3\end{array}$ & $\mathrm{~F} 1$ & $\mathrm{E} 2$ \\
\hline 244AR-New. 10 & Seal Pot overflow & $\begin{array}{l}\text { Release of radioactive contaminated water from } \\
\text { ruptured tank TK-003 or TK-004 to soil } \\
\text { (subsurface) due to vault leaks in } 244-A R \text { Cell } 3\end{array}$ & F1 & E2 \\
\hline 244AR-New.17 & $\begin{array}{l}\text { General Intrusion: Water line } \\
\text { ruptures Snow, Rain }\end{array}$ & $\begin{array}{l}\text { Release of radioactive contaminated water from } \\
\text { ruptured tank TK-002 to soil (subsurface) due to } \\
\text { vault leaks from } 244-A R \text { Cell } 2\end{array}$ & F1 & $\mathrm{E} 2$ \\
\hline 244AR-New.18 & Roof leaks over 244-AR Cell 2 & $\begin{array}{l}\text { Release of radioactive contaminated water to soil } \\
\text { (subsurface) due to vault leak from } 244 \text {-AR Cell } 2\end{array}$ & $\mathrm{Fl}$ & $\mathrm{E} 2$ \\
\hline 244AR-New.19 & Seal Pot overflow & $\begin{array}{l}\text { Release of radioactive contaminated water from } \\
\text { ruptured tank TK-002 to soil (subsurface) due to } \\
\text { vault leaks into } 244-\mathrm{AR} \text { Cell } 2\end{array}$ & $\mathrm{~F} 1$ & $\mathrm{E} 2$ \\
\hline 244AR-New.26 & $\begin{array}{l}\text { General Intrusion: Water line } \\
\text { ruptures Snow, Rain, Failed } \\
\text { equipment tube leaks overflowing } \\
\text { into } 244-\mathrm{AR} \text {, Cell } 1\end{array}$ & $\begin{array}{l}\text { Release of radioactive contaminated water from } \\
\text { ruptured tank TK-001 to soil (subsurface) due to } \\
\text { vault leaks in Cell } 1 \text { of } 244-A R\end{array}$ & $\mathrm{Fl}$ & $\mathrm{E} 2$ \\
\hline 244AR-New.27 & Roof leaks over 244-AR Cell 1 & $\begin{array}{l}\text { Release of radioactive contaminated water to soil } \\
\text { (subsurface) due to vault leak from } 244-\mathrm{AR} \text {, Cell } 1\end{array}$ & F1 & $\mathrm{E} 2$ \\
\hline 244AR-New.30 & $\begin{array}{l}\text { Roof leak over Failed Equipment } \\
\text { Storage Cell }\end{array}$ & $\begin{array}{l}\text { Release of radioactive contaminated water to soil } \\
\text { (subsurface) from } 244-A R \text { Failed Equipment Tube } \\
\text { due to roof leak and leakage from tube }\end{array}$ & $\mathrm{Fl}$ & $\mathrm{E} 2$ \\
\hline 244AR-New.31 & $\begin{array}{l}\text { General Intrusion: Water line } \\
\text { ruptures, Snow, Rain }\end{array}$ & $\begin{array}{l}\text { Release of radioactive contaminated water to soil } \\
\text { (subsurface) from } 244 \text {-AR Failed Equipment Tube } \\
\text { due to roof leak and leakage from tube }\end{array}$ & $\mathrm{F} 1$ & $\mathrm{E} 2$ \\
\hline 244AR-New.34 & $\begin{array}{l}\text { General Intrusion: Vessel vent } \\
\text { prefilter drain, Main vessel vent } \\
\text { filter vault, Vessel Vent Stack }\end{array}$ & $\begin{array}{l}\text { Release of radioactive contaminated water to soil } \\
\text { (subsurface) from } 244-\mathrm{AR} \text { Seal Pot Pit due to in } \\
\text { leakage of liquid into pit resulting in rupture of pot }\end{array}$ & $\mathrm{F} 1$ & $\mathrm{E} 2$ \\
\hline
\end{tabular}


HNF-4453 Rev. 0

This page intentionally left blank 


\begin{tabular}{|c|c|c|c|c|c|c|c|c|c|c|}
\hline $0 \mathrm{H}$ & $\varepsilon S$ & 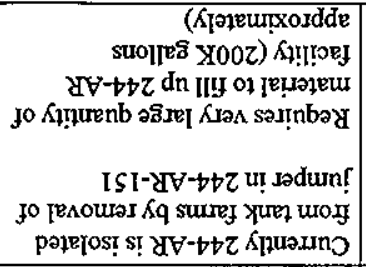 & paṇnbad aưN & parnbay əưoN & parnboy ouoN & pən!nbəy əuoN & 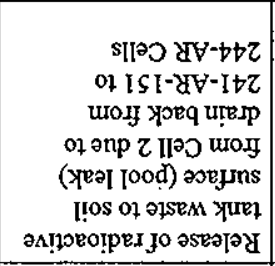 & 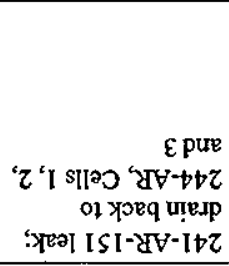 & 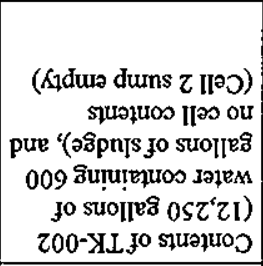 & $\begin{array}{l}9 I^{\prime M \partial N} \\
-2 \forall t b Z \\
\end{array}$ \\
\hline of & ES & 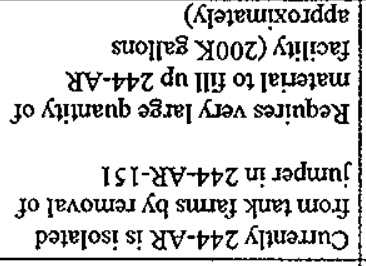 & pəג!nbay auoN & pan!nbəy auoN & parṭbəy əuoN & pat!nbay әuoN & 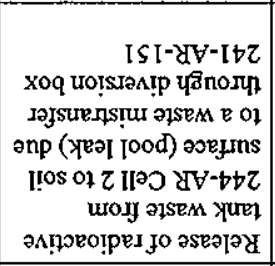 & 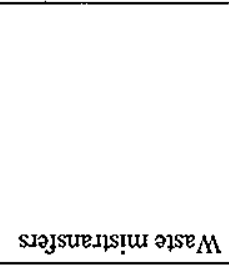 & 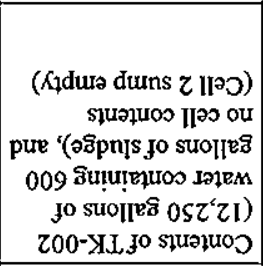 & $\begin{array}{l}S I M \partial N \\
-d V t t z \\
\end{array}$ \\
\hline OA & ES & 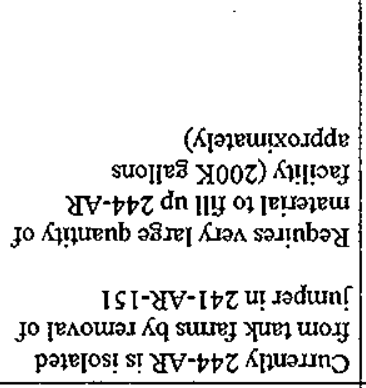 & paṛnbay əuoN & pəunnbəy әuоN & paj!nbay auoN & pəu!nbəY əuoN & 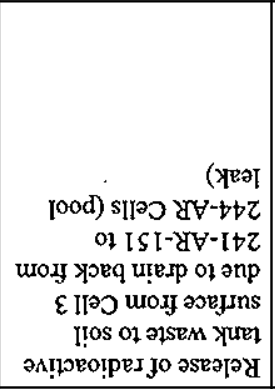 & 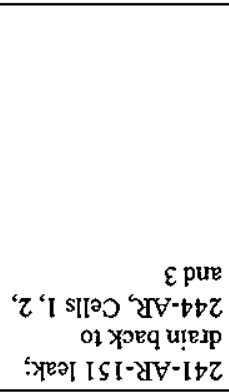 & 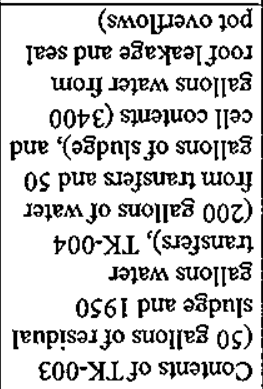 & $\begin{array}{l}90 \mathrm{M} 2 \mathrm{~N} \\
-\mathrm{YH} t \not \mathrm{C}\end{array}$ \\
\hline $\mathrm{OH}$ & $\varepsilon S$ & 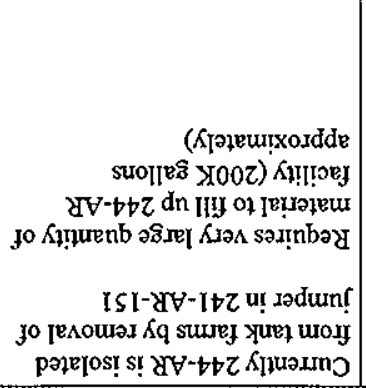 & pəu!nbəy əuoN & pəu!nboy ouoN & paxtnbay әuoN & pa!nbəy aưoN & 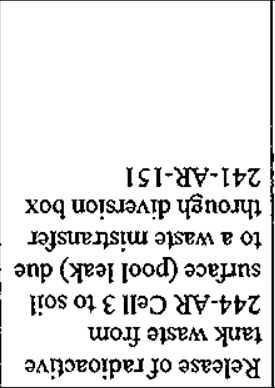 & SIəJsurens! & 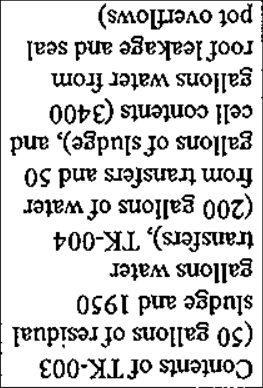 & $\begin{array}{l}\text { SOMaN } \\
-4 \forall t t z\end{array}$ \\
\hline \multicolumn{11}{|c|}{ 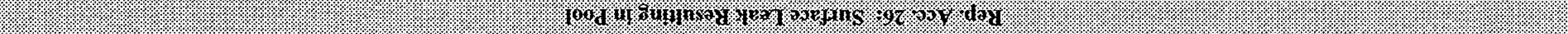 } \\
\hline $\begin{array}{l}\text { PEO } \\
\text { baxH }\end{array}$ & $\begin{array}{l}\text { jes } \\
\text { uop }\end{array}$ & sצ.reury & 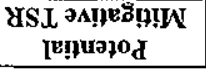 & 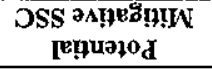 & 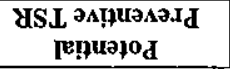 & 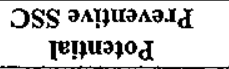 & uoṇpPUOO SnOP.IEZEH & asnep & YvW & 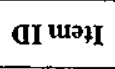 \\
\hline \multicolumn{11}{|c|}{ 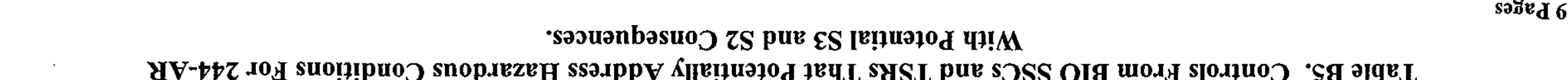 } \\
\hline
\end{tabular}




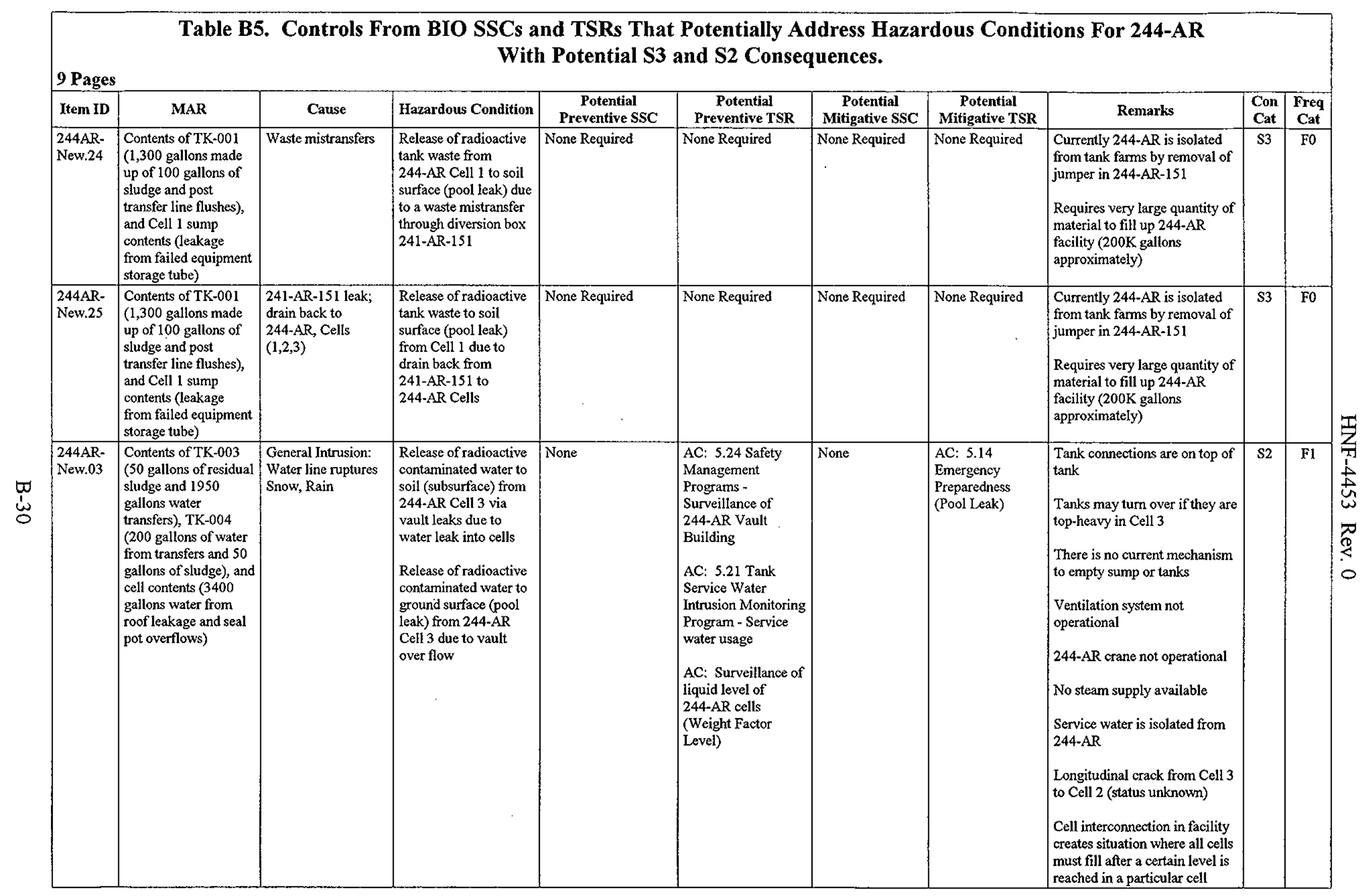




\begin{tabular}{|c|c|c|c|c|c|c|c|c|c|c|}
\hline \multicolumn{11}{|c|}{$\begin{array}{l}\text { Table B5. Controls From BIO SSCs and TSRs That Potentially Address Hazardous Conditions For 244-AR } \\
\text { With Potential S3 and S2 Consequences. }\end{array}$} \\
\hline Item ID & MAR & Cause & Hazardous Condition & $\begin{array}{c}\text { Potential } \\
\text { Preventive SSC }\end{array}$ & $\begin{array}{c}\text { Potential } \\
\text { Preventive TSR }\end{array}$ & $\begin{array}{c}\text { Potential } \\
\text { Mitigative SSC }\end{array}$ & $\begin{array}{c}\text { Potential } \\
\text { Mitigative TSR }\end{array}$ & Remarks & $\begin{array}{l}\text { Con } \\
\text { Cat }\end{array}$ & $\begin{array}{c}\text { Freq } \\
\text { Cat }\end{array}$ \\
\hline $\begin{array}{l}\text { 244AR- } \\
\text { New.04 }\end{array}$ & $\begin{array}{l}\text { Contents of TK-003 } \\
\text { (50 gallons of residual } \\
\text { sludge and } 1950 \\
\text { gallons water } \\
\text { transfers), TK-004 } \\
\text { (200 gallons of water } \\
\text { from transfers and } 50 \\
\text { gallons of sludge), and } \\
\text { cell contents ( } 3400 \\
\text { gallons water from } \\
\text { roof leakage and seal } \\
\text { pot overflows) }\end{array}$ & $\begin{array}{l}\text { Roof leaks over } \\
\text { 244-AR Cell } 3\end{array}$ & $\begin{array}{l}\text { Release of radioactive } \\
\text { contaminated water to } \\
\text { soil (subsurface) from } \\
244-\mathrm{AR} \text { Cell } 3 \text { via } \\
\text { vault leaks } \\
\text { Release of radioactive } \\
\text { contaminated water to } \\
\text { ground surface (pool } \\
\text { leak) } 244-\mathrm{AR} \text { Cell } 3 \\
\text { due to vault over flow }\end{array}$ & None & $\begin{array}{l}\text { AC: } 5.24 \text { Safety } \\
\text { Management } \\
\text { Programs - } \\
\text { Surveillance of } \\
\text { 244-AR Vault } \\
\text { Building } \\
\text { AC: Surveillance of } \\
\text { liquid level of } \\
\text { 244-AR cells } \\
\text { (Weight Factor } \\
\text { Level) }\end{array}$ & None & $\begin{array}{l}\text { AC: } 5.14 \\
\text { Emergency } \\
\text { Preparedness } \\
\text { (Pool Leak) }\end{array}$ & $\begin{array}{l}\text { Tank connections are on top of } \\
\text { tank } \\
\text { Tanks may turn over if they are } \\
\text { top-heavy in Cell } 3 \\
\text { There is no current mechanism } \\
\text { to empty sump or tanks } \\
\text { Ventilation system not } \\
\text { operational } \\
\text { 244-AR crane not operational } \\
\text { No steam supply available } \\
\text { Longitudinal crack from Cell } 3 \\
\text { to Cell } 2 \text { (status unknown) } \\
\text { Cell interconnection in facility } \\
\text { creates situation where all cells } \\
\text { must fill after a certain level is } \\
\text { reached in a particular cell }\end{array}$ & s2 & $\mathrm{F} 1$ \\
\hline $\begin{array}{l}\text { 244AR- } \\
\text { New.07 }\end{array}$ & $\begin{array}{l}\text { Contents of TK-003 } \\
\text { ( } 50 \text { gallons of residual } \\
\text { sludge and } 1950 \\
\text { gallons water } \\
\text { transfers), TK-004 } \\
\text { ( } 200 \text { gallons of water } \\
\text { from transfers and } 50 \\
\text { gallons of sludge), and } \\
\text { cell contents (3400 } \\
\text { gallons water from } \\
\text { roof leakage and seal } \\
\text { pot overflows) }\end{array}$ & $\begin{array}{l}\text { 244-AR Seal Pot } \\
\text { overflow into Cell } 3\end{array}$ & $\begin{array}{l}\text { Release of radioactive } \\
\text { contaminated water to } \\
\text { soil (subsurface) from } \\
244-\text { AR Cell } 3 \text { via } \\
\text { vault leaks due to } \\
\text { water intrusion into } \\
\text { seal pot } \\
\text { Release of radioactive } \\
\text { contaminated water to } \\
\text { ground surface (pool } \\
\text { leak) from } 244-\mathrm{AR} \\
\text { Cell } 3 \text { due to vault } \\
\text { over flow }\end{array}$ & None & $\begin{array}{l}\text { AC: } 5.24 \text { Safety } \\
\text { Management } \\
\text { Programs - } \\
\text { Surveillance of } \\
\text { 244-AR Vault } \\
\text { Building } \\
\\
\text { AC: } 5.21 \text { Tank } \\
\text { Service Water } \\
\text { Intrusion Monitoring } \\
\text { Program - Service } \\
\text { water usage } \\
\text { AC: Surveillance of } \\
\text { liquid level of } \\
\text { 244-AR cells } \\
\text { (Weight Factor } \\
\text { Level) }\end{array}$ & None & $\begin{array}{l}\text { AC: } 5.14 \\
\text { Emergency } \\
\text { Preparedness } \\
\text { (Pool Leak) }\end{array}$ & $\begin{array}{l}\text { Tank connections are on top of } \\
\text { tank } \\
\text { Tanks may turn over if they are } \\
\text { top-heavy in Cell } 3 \\
\text { There is no current mechanism } \\
\text { to empty sump or tanks } \\
\text { Ventilation system not } \\
\text { operational } \\
\text { 244-AR crane not operational } \\
\text { No steam supply available } \\
\text { Longitudinal crack from Cell } 3 \\
\text { to Cell } 2 \text { (status unknown) } \\
\text { Cell interconnection in facility } \\
\text { creates situation where all cells } \\
\text { must fill after a certain level is } \\
\text { reached in a particular cell }\end{array}$ & S2 & F1 \\
\hline
\end{tabular}




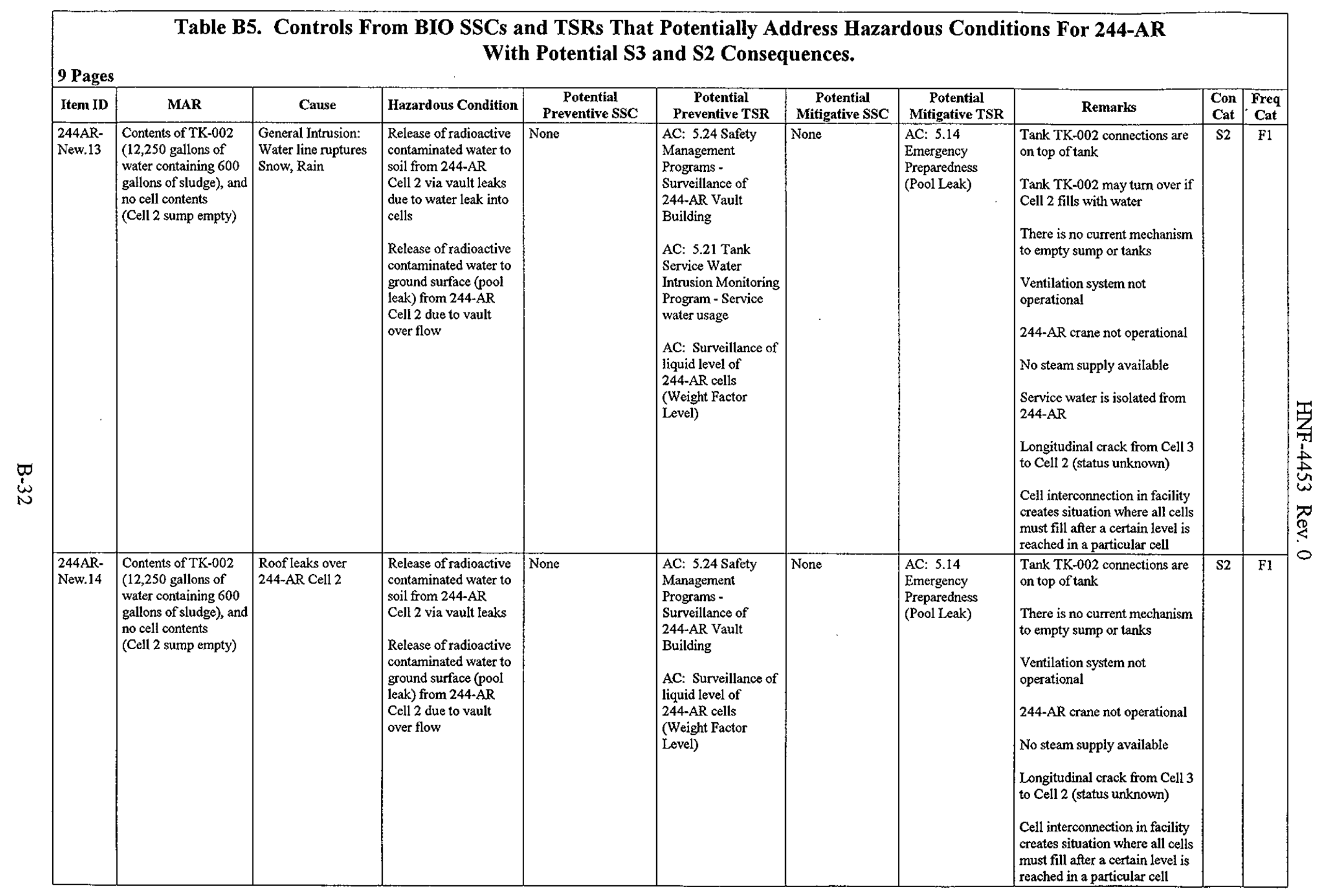




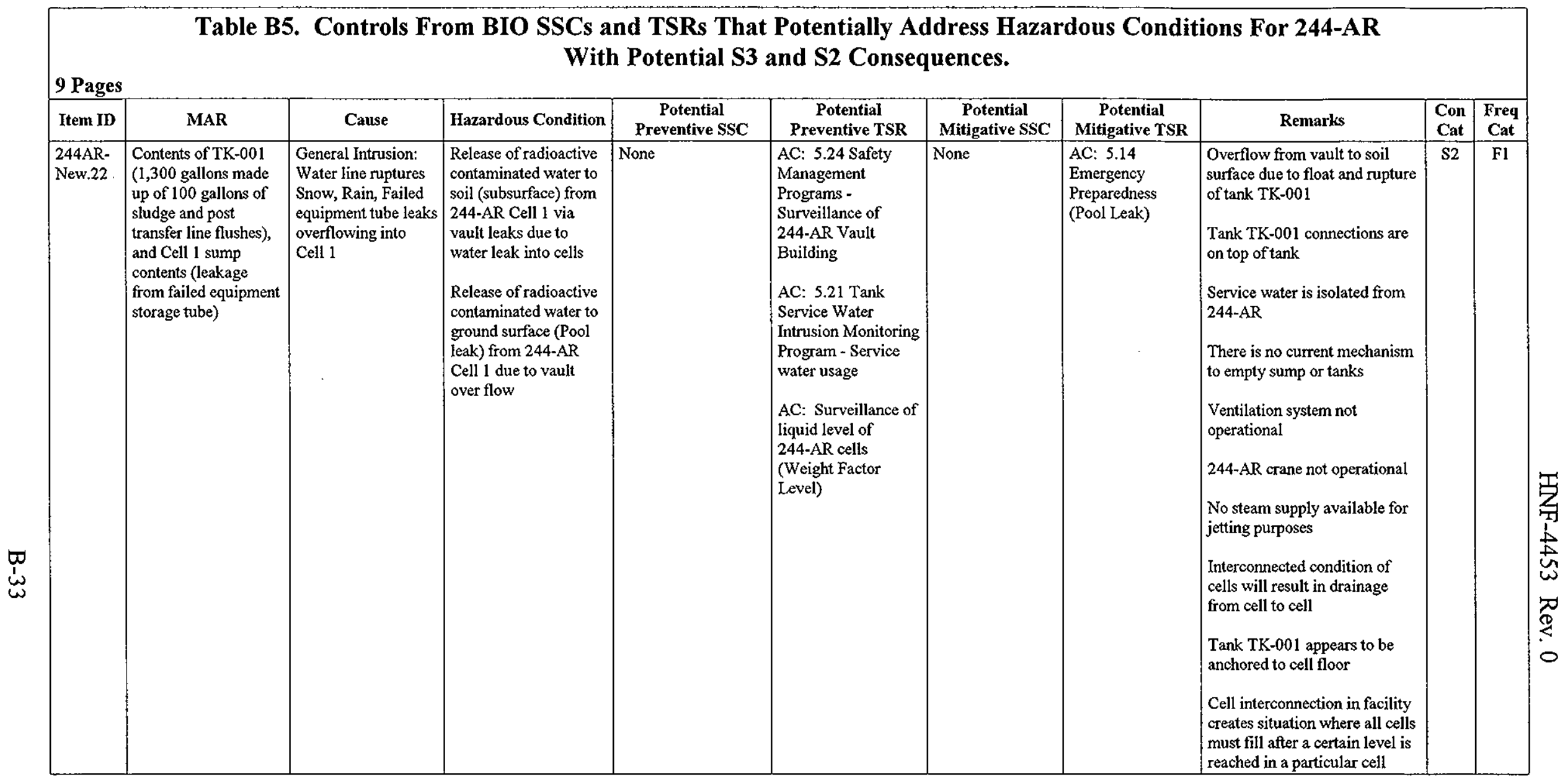




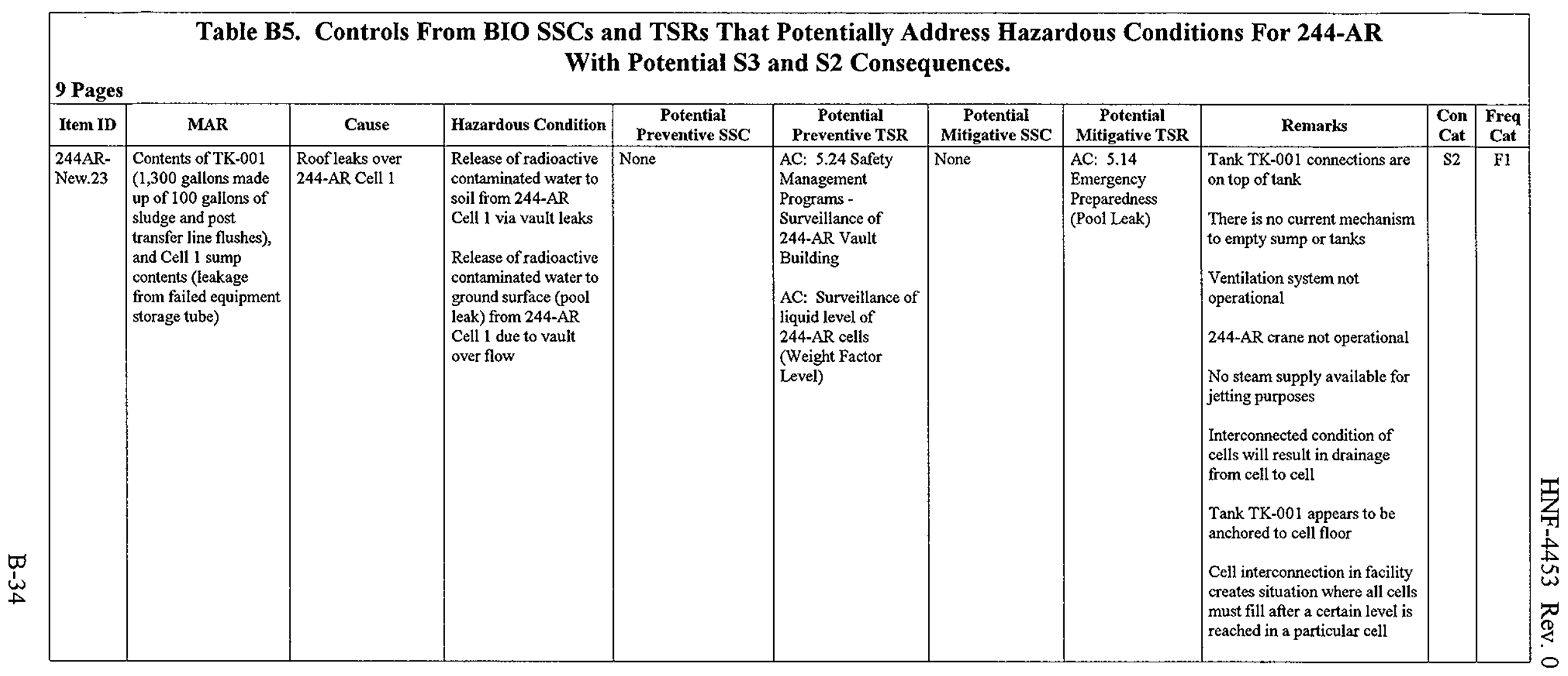


HNF-4453 Rev. 0

This page intentionally left blank

B-35 


\begin{tabular}{|c|c|c|c|c|c|c|c|c|}
\hline \multicolumn{9}{|c|}{ Table B6. S2 and S3 Hazardous Conditions Sequenced By BIO Accident Section } \\
\hline BIN & ID & MAR & Cause & Hazardous Condition & $\begin{array}{l}\text { Cons } \\
\text { Cat }\end{array}$ & $\begin{array}{r}\text { Freq } \\
\text { Cat }\end{array}$ & $\begin{array}{l}\text { Cause } \\
\text { Grp }\end{array}$ & $\begin{array}{l}\text { Rep } \\
\text { Acc }\end{array}$ \\
\hline \multicolumn{9}{|c|}{ 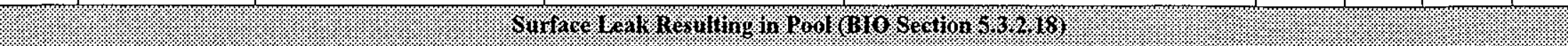 } \\
\hline : & (1050 & 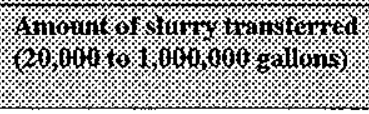 & 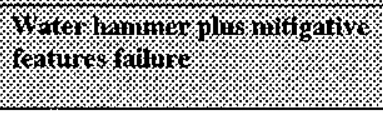 & 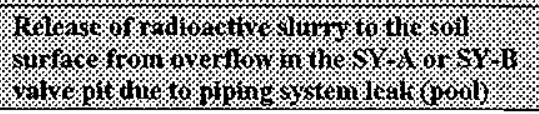 & . & 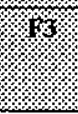 & W & 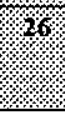 \\
\hline \multicolumn{9}{|c|}{ 244-AR Vault Hazardous Conditions } \\
\hline C-2-b & 244AR-New.05 & $\begin{array}{l}\text { Contents of TK-003 (50 gallons } \\
\text { of residual sludge and } 1950 \\
\text { gallons water transfers), TK-004 } \\
\text { ( } 200 \text { gallons of water from } \\
\text { transfers and } 50 \text { gallons of } \\
\text { sludge), and cell contents ( } 3400 \\
\text { gallons water from roof leakage } \\
\text { and seal pot overflows) }\end{array}$ & Waste mistransfers & $\begin{array}{l}\text { Release of radioactive tank waste from 244-AR } \\
\text { Cell } 3 \text { to soil surface (pool leak) due to a waste } \\
\text { mistransfer through diversion box } 241 \text {-AR-151 }\end{array}$ & S3 & F0 & D06 & $26 \mathrm{X}$ \\
\hline$C-2-b$ & 244AR-New.06 & $\begin{array}{l}\text { Contents of TK-003 } 50 \text { gallons } \\
\text { of residual sludge and } 1950 \\
\text { gallons water transfers), TK-004 } \\
\text { ( } 200 \text { gallons of water from } \\
\text { transfers and } 50 \text { gallons of } \\
\text { sludge), and cell contents ( } 3400 \\
\text { gallons water from roof leakage } \\
\text { and seal pot overflows) }\end{array}$ & $\begin{array}{l}\text { 241-AR-151 leak; drain back to } \\
\text { 244-AR; Cells 1, 2, and 3 }\end{array}$ & $\begin{array}{l}\text { Release of radioactive tank waste to soil surface } \\
\text { from Cell } 3 \text { due to drain back from 241-AR-151 } \\
\text { to 244-AR Cells (pool leak) }\end{array}$ & S3 & F0 & D06 & $26 \mathrm{X}$ \\
\hline$c-2-b$ & 244AR-New.15 & $\begin{array}{l}\text { Contents of TK- } 002 \text { (12,250 } \\
\text { gallons of water containing } 600 \\
\text { gallons of sludge), and no cell } \\
\text { contents (Cell } 2 \text { sump empty) }\end{array}$ & Waste mistransfers & $\begin{array}{l}\text { Release of radioactive tank waste from } 244-\mathrm{AR} \\
\text { Cell } 2 \text { to soil surface (pool leak) due to a waste } \\
\text { mistransfer through diversion box 241-AR-151 }\end{array}$ & S3 & Fo & D06 & $26 \mathrm{X}$ \\
\hline$c-2-b$ & 244AR-New.16 & $\begin{array}{l}\text { Contents of } T K-002 \text { ( } 12,250 \\
\text { gallons of water containing } 600 \\
\text { gallons of sludge), and no cell } \\
\text { contents (Cell } 2 \text { sump empty) }\end{array}$ & $\begin{array}{l}\text { 241-AR-151 leak; drain back to } \\
\text { 244-AR, Cells } 1,2 \text {, and } 3\end{array}$ & $\begin{array}{l}\text { Release of radioactive tank waste to soil surface } \\
\text { (pool leak) from Cell } 2 \text { due to drain back from } \\
241-A R-151 \text { to } 244-A R \text { Cells }\end{array}$ & S3 & Fo & D06 & $26 \mathrm{X}$ \\
\hline C-2-b & 244AR-New.24 & $\begin{array}{l}\text { Contents of TK-001 }(1,300 \\
\text { gallons made up of } 100 \text { gallons } \\
\text { of sludge and post transfer line } \\
\text { flushes), and Cell 1 sump } \\
\text { contents (leakage from failed } \\
\text { equipment storage tube) }\end{array}$ & Waste mistransfers & $\begin{array}{l}\text { Release of radioactive tank waste from 244-AR } \\
\text { Cell I to soil surface (pool leak) due to a waste } \\
\text { mistransfer through diversion box 241-AR-151 }\end{array}$ & S3 & Fo & D06 & $26 \mathrm{X}$ \\
\hline C-2-b & 244AR-New.25 & $\begin{array}{l}\text { Contents of TK-001 }(1,300 \\
\text { gallons made up of } 100 \text { gallons } \\
\text { of sludge and post transfer line } \\
\text { flushes), and Cell 1 sump } \\
\text { contents (leakage from failed } \\
\text { equipment storage tube) }\end{array}$ & $\begin{array}{l}\text { 241-AR-151 leak; drain back to } \\
\text { 244-AR, Cells }(1,2,3)\end{array}$ & $\begin{array}{l}\text { Release of radioactive tank waste to soil surface } \\
\text { (pool leak) from Cell } 1 \text { due to drain back from } \\
241-A R-151 \text { to 244-AR Cells }\end{array}$ & s3 & Fo & D06 & $26 \mathrm{X}$ \\
\hline
\end{tabular}


Table B6. S2 and S3 Hazardous Conditions Sequenced By BIO Accident Section

\begin{tabular}{|c|c|c|c|c|c|c|c|c|}
\hline \multicolumn{9}{|c|}{ Table B6. S2 and S3 Hazardous Conditions Sequenced By BIO Accident Section } \\
\hline BIN & ID & MAR & Cause & Hazardous Condition & $\begin{array}{l}\text { Cons } \\
\text { Cat }\end{array}$ & $\begin{array}{l}\text { Freq } \\
\text { Cat }\end{array}$ & $\begin{array}{l}\text { Cause } \\
\text { Grp }\end{array}$ & $\begin{array}{l}\text { Rep } \\
\text { Acc }\end{array}$ \\
\hline$c-2-b$ & 244AR-New.03 & $\begin{array}{l}\text { Contents of TK-003 ( } 50 \text { gallons } \\
\text { of residual sludge and } 1950 \\
\text { gallons water transfers), TK-004 } \\
(200 \text { gallons of water from } \\
\text { transfers and } 50 \text { gallons of } \\
\text { sludge), and cell contents ( } 3400 \\
\text { gallons water from roof leakage } \\
\text { and seal pot overflows) }\end{array}$ & $\begin{array}{l}\text { General Intrusion: Water line } \\
\text { ruptures Snow, Rain }\end{array}$ & $\begin{array}{l}\text { Release of radioactive contaminated water to soil } \\
\text { (subsurface) from } 244 \text {-AR Cell } 3 \text { via vault leaks } \\
\text { due to water leak into cells } \\
\text { Release of radioactive contaminated water to } \\
\text { ground surface (pool leak) from } 244-A R \text { Cell } 3 \\
\text { due to vault over flow }\end{array}$ & S2 & F1 & D19 & $26 \mathrm{X}$ \\
\hline c-2-b & 244AR-New.04 & $\begin{array}{l}\text { Contents of TK-003 ( } 50 \text { gallons } \\
\text { of residual sludge and } 1950 \\
\text { gallons water transfers), TK-004 } \\
\text { ( } 200 \text { gallons of water from } \\
\text { transfers and } 50 \text { gallons of } \\
\text { sludge), and cell contents ( } 3400 \\
\text { gallons water from roof leakage } \\
\text { and seal pot overflows) }\end{array}$ & Roof leaks over 244-AR Cell 3 & $\begin{array}{l}\text { Release of radioactive contaminated water to soil } \\
\text { (subsurface) from 244-AR Cell } 3 \text { via vault leaks } \\
\text { Release of radioactive contaminated water to } \\
\text { ground surface (pool leak) 244-AR Cell } 3 \text { due to } \\
\text { vault over flow }\end{array}$ & \$2 & $\mathrm{F} 1$ & D19 & $26 \mathrm{X}$ \\
\hline$c-2-b$ & 244AR-New.07 & $\begin{array}{l}\text { Contents of TK- } 003 \text { ( } 50 \text { gallons } \\
\text { of residual sludge and } 1950 \\
\text { gallons water transfers), TK-004 } \\
\text { (200 gallons of water from } \\
\text { transfers and } 50 \text { gallons of } \\
\text { sludge), and cell contents ( } 3400 \\
\text { gallons water from roof leakage } \\
\text { and seal pot overflows) }\end{array}$ & $\begin{array}{l}\text { 244-AR Seal Pot overflow into } \\
\text { Cell } 3\end{array}$ & $\begin{array}{l}\text { Release of radioactive contaminated water to soil } \\
\text { (subsurface) from } 244 \text {-AR Cell } 3 \text { via vault leaks } \\
\text { due to water intrusion into seal pot } \\
\text { Release of radioactive contaminated water to } \\
\text { ground surface (pool leak) from } 244-\mathrm{AR} \text { Cell } 3 \\
\text { due to vault over flow }\end{array}$ & S2 & F1 & D19 & $26 \mathrm{X}$ \\
\hline $\mathrm{C}-2-\mathrm{b}$ & 244AR-New.13 & $\begin{array}{l}\text { Contents of TK-002 ( } 12,250 \\
\text { gallons of water containing } 600 \\
\text { gallons of sludge), and no cell } \\
\text { contents (Cell } 2 \text { sump empty) }\end{array}$ & $\begin{array}{l}\text { General Intrusion: Water line } \\
\text { ruptures Snow, Rain }\end{array}$ & $\begin{array}{l}\text { Release of radioactive contaminated water to soil } \\
\text { from } 244-A R \text { Cell } 2 \text { via vault leaks due to water } \\
\text { leak into cells } \\
\text { Release of radioactive contaminated water to } \\
\text { ground surface (pool leak) from } 244-\mathrm{AR} \text { Cell } 2 \\
\text { due to vault over flow }\end{array}$ & \$2 & F1 & D19 & $26 \mathrm{X}$ \\
\hline $\mathrm{c}-2-\mathrm{b}$ & 244AR-New.14 & $\begin{array}{l}\text { Contents of TK-002 (12,250 } \\
\text { gallons of water containing } 600 \\
\text { gallons of sludge), and no cell } \\
\text { contents (Cell } 2 \text { sump empty) }\end{array}$ & Roof leaks over 244-AR Cell 2 & $\begin{array}{l}\text { Release of radioactive contaminated water to soil } \\
\text { from 244-AR Cell } 2 \text { via vault leaks } \\
\text { Release of radioactive contaminated water to } \\
\text { ground surface (pool leak) from 244-AR Cell } 2 \\
\text { due to vault over flow }\end{array}$ & \$2 & F1 & D19 & $26 \mathrm{X}$ \\
\hline$c-2-b$ & 244AR-New.22 & $\begin{array}{l}\text { Contents of TK- } 001 \text { ( } 1,300 \\
\text { gallons made up of } 100 \text { gallons } \\
\text { of sludge and post transfer line } \\
\text { flushes), and Cell } 1 \text { sump } \\
\text { contents (leakage from failed } \\
\text { equipment storage tube) }\end{array}$ & $\begin{array}{l}\text { General Intrusion: Water line } \\
\text { ruptures Snow, Rain, Failed } \\
\text { equipment tube leaks overflowing } \\
\text { into Cell I }\end{array}$ & $\begin{array}{l}\text { Release of radioactive contaminated water to soil } \\
\text { (subsurface) from } 244-\mathrm{AR} \text { Cell } 1 \text { via vault leaks } \\
\text { due to water leak into cells } \\
\text { Release of radioactive contaminated water to } \\
\text { ground surface (Pool leak) from 244-AR Cell } 1 \\
\text { due to vault over flow }\end{array}$ & \$2 & $\mathrm{Fl}$ & D19 & $26 \mathrm{X}$ \\
\hline
\end{tabular}




\begin{tabular}{|c|c|c|c|c|c|c|c|c|}
\hline \multicolumn{9}{|c|}{ Table B6. S2 and S3 Hazardous Conditions Sequenced By BIO Accident Section } \\
\hline BIN & ID & MAR & Cause & Hazardous Condition & $\begin{array}{l}\text { Cons } \\
\text { Cat }\end{array}$ & $\begin{array}{l}\text { Freq } \\
\text { Cat }\end{array}$ & $\begin{array}{l}\text { Cause } \\
\text { Grp }\end{array}$ & $\begin{array}{l}\text { Rep } \\
\text { Acc }\end{array}$ \\
\hline $\mathrm{C}-2 \cdot \mathrm{b}$ & 244AR-New.23 & $\begin{array}{l}\text { Contents of } \Upsilon \mathrm{K}-001 \text { (1,300 } \\
\text { gallons made up of } 100 \text { gallons } \\
\text { of sludge and post transfer line } \\
\text { flushes), and Cell } 1 \mathrm{sump} \\
\text { contents (leakage from failed } \\
\text { equipment storage tube) }\end{array}$ & Roof leaks over 244-AR Cell I & $\begin{array}{l}\text { Release of radioactive contaminated water to soil } \\
\text { from 244-AR Cell } 1 \text { via vault leaks } \\
\text { Release of radioactive contaminated water to } \\
\text { ground surface (pool leak) from 244-AR Cell } 1 \\
\text { due to vault over flow }\end{array}$ & $\$ 2$ & F1 & D19 & $26 \mathrm{X}$ \\
\hline
\end{tabular}


HNF-4453 Rev. 0

This page intentionally left blank 
HNF-4453 Rev. 0

Appendix C

Peer Review Checklist

C-1 
HNF-4453 Rev. 0

Practice 1342901112

Publication Date 01Mar99

Attachment 02 - Sheet 1 of 1

FLUOR DANIEL NORTHWEST

TECHNICAL, PEER REVIEWS

\section{CHECKLIST FOR TECHNICAL PEER REVIEW}

Document Reviewed:

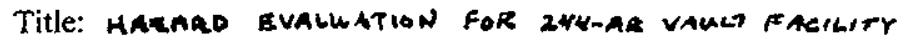

Author: D. T. BRAmN

Date: $5 / 8 / 99$

Scope of Review:

Yes No* NA

[V] ] [ ]** Previous reviews complete and cover analysis, up to scope of this review, with no gaps.

[ $\checkmark[$ ] [ ] Problem completely defined.

[V] ] [ ] Accident scenarios developed in a clear and logical manner.

[ $\mathrm{V}][$ ] [ ] Necessary assumptions explicitly stated and supported.

[ ] [ ] [ 5 Computer codes and data files documented.

[ ] [ ] [ J Data used in calculations explicitly stated in document.

[ J [ ] [ ] Data checked for consistency with original source information as applicable.

[ ] [ ] [ ] Mathematical derivations checked including dimensional consistency of results.

[ ] [ ] [ ] Models appropriate and used within range of validity or use outside range of established validity justified.

[ ] [ ] 4 Hand calculations checked for errors. Spreadsheet results should be treated exactly the same as hand calculations.

[ ] [ ] [ $]$ Software input correct and consistent with document reviewed.

[ ] [ ] [V]. Software output consistent with input and with results reported in document reviewed.

[ $1[$ I[ ] Limits/criteria/guidelines applied to analysis results are appropriate and referenced.

Limits/criteria/guidelines checked against references.

[ ] ] [ [ ]

$[\sqrt{2}[][]$

$[\checkmark[][]$

[ $Y[][]$

[ ] $[v]^{* *}$

[V] ][]

Safety margins consistent with good engineering practíces.

Conclusions consistent with analytical results and applicable limits.

Results and conclusions address all points required in the problem statement.

Format consistent with applicable guides or other standards.

Traceability R REERENCES CHECKED

[V] ] [ ] Document approved (for example, the reviewer affirms the technical accuracy of the document).

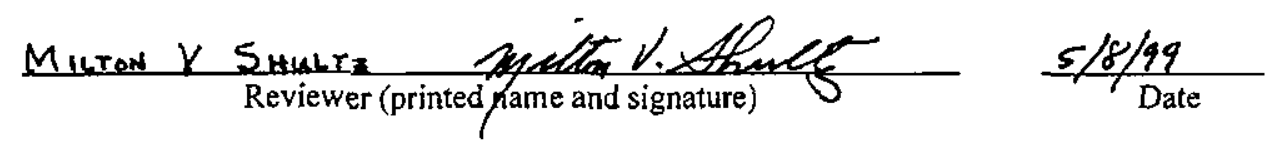

* All "no" responses must be explained below or on an additional sheet.

** Any calculations, comments, or notes generated as part of this review should be signed, dated, and attached to this checklist. Such material should be labeled and recorded in such a manner as to be intelligible to a technically qualified third party. 


\section{DISTRIBUTION SHEET}

To

Distribution

Project Title/Work Order

Hazard Evaluation for 244-AR Vault

Name

J. W. Bloom

W. H. Grams

S. S. Gahix

G. L. Jones

E. J. Lipke

J. E. Meacham

Central Files

Licensing Files (C. J. Williams)
From

J. W. Bloom
Page 1 of 1

Date June 14, 1999

EDT No. 66720

ECN No. N/A

\begin{tabular}{c|c|c|c|c|} 
MSIN & $\begin{array}{c}\text { Text } \\
\text { With All } \\
\text { Attach. }\end{array}$ & Text Only & $\begin{array}{c}\text { Attach.I } \\
\text { Appendix } \\
\text { Only }\end{array}$ & $\begin{array}{c}\text { EDT/ECN } \\
\text { Only }\end{array}$ \\
\hline
\end{tabular}

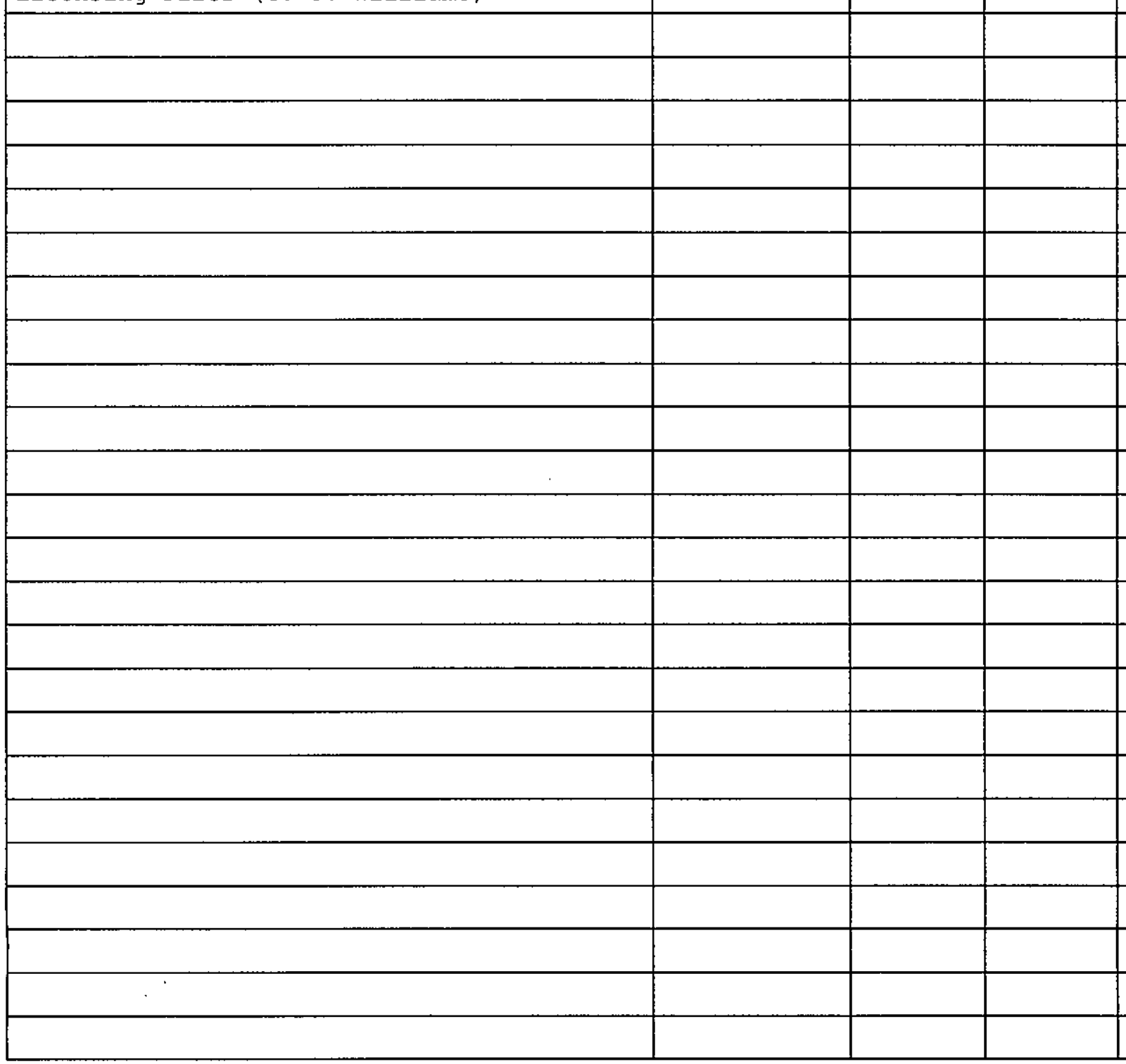

RI -49

R1-49

RI -49

$\mathrm{R} 1-44$

R1-49

R1-49

A3-88

$x$

$\mathrm{x}$

$x$

$\mathrm{x}$

$x$

$\mathrm{x}$

$\mathrm{X}$ 